\title{
DE VERHOUDING VAN HET OUDJAVAANSCHE UDYOGAPARWA TOT ZIJN SANSKRT- ORIGINEEL.
}

DOoR Dr. H. H. JUYNBOLL.

De Oudjavaansche paraphrase van het Udyogaparwa of vijfde boek van het Mahâbhârata is blijkens de taal even oud als de vertaling van het Âdi-, Wirâța- en Bhîșmaparwa en ouder dan die der vier laatste parwa's, die waarschijnlijk vertaald zijn in een tijd, toen de taal reeds tot het Middeljavaansch begon te naderen.

Voor eene volledige tekstuitgave is het Udyogaparwa niet geschikt, daar dit parwa, zooals Dr. van der Tuuk reeds opmerkte (Journ. R. As. Soc. XIII, 48 en Kawi-Bal. Wdb. I, 170 , s.v. Udyoga), het meest corrupte van alle parwa's en vol lacunen is, terwijl bovendien het begin en het slot ontbreken.

Toch kan het nuttig zijn, door vergelijking met den Sanskrttekst vast te stellen, in welke verhouding de Oudjavaansche vertaling tot zijn origineel staat. Het meest geschikte middel hiertoe is de vergelijking der talrijke aangehaalde Sanskṛt-verzen in de O. Jav. bewerking met die van den Sanskṛt-tekst. Hoewel deze verzen, evenals in het Âdi-en Wirâța parwa gewoonlijk zeer verbasterd zijn, ben ik er toch in geslaagd, al deze citaten in de Calcutta-editie van den Sanskrt-tekst terug te vinden.

Bij de vergelijking hebben wij het goede lontarhandschrift 959a van het Bataviaasch Genootschap, beschreven als cod. MCCXVI in deel II van mijn Supplement op den Cat. der Jav. en Mad. HSS. der Leidsche Universiteitsbibliotheek (pag. 155) tot grondslag genomen. Dit HS., dat in 1747 Çâka $=1825$ A.D. geschreven is, zal verder met $\mathrm{J}$ aangeduid worden, terwijl wij de Calcutta-uitgave van den Sanskrtt-tekst kortheidshalve S zullen noemen. De cijfers, gevoegd bij J hebben betrekking op de palmbladen van cod. $959^{a}$, die van $\mathrm{S}$ op de verzen van de Calcutta-editie.

In het vervolg zullen wij op de verbasterde aanhalingen de tegenwoordige lezing laten volgen en daarna de Oudjav. vertaling met eene Nederlandsche overzetting, voor zoover die 
mogelijk is met het oog op den tegenwoordigen stand der kennis van het Oudjavaansch.

Blijkens cod. 5020 van de Lombok-collectie ontbreken in cod. $959 a$, evenals in cod. 3736 (van de verzameling van dr. van der Tuuk) en in cod. 5028 (van de Lombok-collectie), in het begin de lettergrepen yadya. Hierop volgt: (yadya)pin tunggala kawitanya, tathâpi amogha dudû prawṛtinya; en daarna: phalaphalawati sakâ yatekasmin wanasyato $=\mathrm{S}$. $43 b$ : phalâphalawatî çâkhe yathaikasmin wanaspatau. J. kadyangga ning pang ning kayu-kayu, hanâwwah hana tan pawwah: "evenals de takken der boomen, er zijn er met vruchten en er zijn er zonder vruchten». In mijn proefschrift (Drie boeken van het O.-Jav. Mahâbhârata, p. 17) wees $\mathrm{ik}$ er reeds op, dat deze O.-Jav. woorden de vertaling bevatten van çloka $43 b$ van den Sanskṛttekst (het cijfer $48 b$ daar is een drukfout).

J. fol. 2 ; r. 4: Pûrwwañ câbhigatam santo bhajante pûrwwacâriṇa(ḥ),

twañ ca çreșţhatamo loke satamadhye Janarddhanaḥ $=$ S. $142:{ }^{\circ}$ satâm adya Janârddana.

J. ikâ sang mahâpuruṣa ngaran ira, asing rumuhụ̣ ḍatang pwa rakwa pinaritrâna nira, mahârâja pwa ya ta, prasiddha wiçeșa ning sajjana ngke ring loka: "hij, die een groot man heet, helpt dengene, die het eerst komt, en gij, vorst, zijt gebleken de voortreffelijkste der goede menschen hier in de wereld te zijn.»

J. fol. a, 3, r. 2. Tawa pûrwwam bhigamânât pûrwwam câpyasya darçanât,

sahâryyam ubhayor ewa karisyami Suyodhanah.

S. 145: tawa pûrbbâbhigamanât..... sahâyyam ubhayor ewa kariṣyâmi Suyodhana.

J. rahadyan sanghulun kalih, kapwâropana ni nghulun, phala ning rumuhuṇ ḍatěng, mwang priya ning rumuhun katon: "gij beiden zult door mij geholpen worden, als belooning voor het eerste komen en ter wille van het eerst gezien worden». K ṛṣna zegt deze woorden tot Arjuna en tot Duryodhana, die beiden zijn hulp komen inroepen: Arjuna is n.l. het eerst door Kṛṣna gezien, terwijl Duryodhana het eerst gekomen is. J. fol. 4, r. 2: Tatra pâlyo'rjjuno râjan yadi matpriyam icchasi,

tejowaddhaçwa te kâryyah Soter asmat priyawahạ. S. 215 :.... tejobadhaçca .... Sauter asmaj jayâwahạ̣. 
J. anuratsanâk iking Dhanañjaya de ni bapa ni nghulun, yan hanâsih rahadyan sanghulun ing pinakanghulun, ngěntyakěnta kaçaktin i Karṇṇa, samârgganỵa pějaha tah, ișta prayojana parameçwara: "Dhanañjaya, mijn kind hier, moet beschermd worden door mijn vader, wanneer gij mij genegen zijt, maak een einde aan de macht van Karna, opdat hij sterve, dat is de wensch en het doel van den vorst».

In het begin is de O.J. tekst corrupt; waarschijnlijk moet men lezen: anu rakṣan anak. De $t$ en $k$ worden n.l. dikwijls verward, omdat zij in het oude schrift veel op elkaar gelijken. In elk geval is de corrupte uitdrukking de vertaling van pâlya $=$ moet beschermd worden, te beschermen.

J. fol. 4, r. 3. Jațâsurât parikleçah Ticcatañca mahâdyute,

Dropadyâpigatan duhkami Damayantya mahâçubham.

S. 223: .... Kîcakâc ca mahâdyute, Draupadyâ' dhigatam sarwwam Damayantyâ yathâ' çubham.

J. muwah kalaranta ri kâla ning daitya Jațâsuracarita, mwang ri kâla ning Kîcakacarita, kadi sang Damayantî juga sira: "En uw leed tijdens de geschiedenis van den daemon Jaṭâsura en tijdens de geschiedenis van Kîcaka was even groot als dat van Damayantî.»

Jațâsura was een daemon, die zich als een brahmaan vermomde en Yudhișțhira, Sahadewa, Nakula en Drau padî wegvoerde.

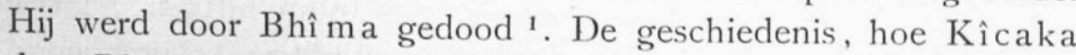
door Bhîma gedood werd, omdat hij Draupadî wilde verleiden, is in het Wirâțaparwa uitvoerig verhaald ${ }^{2}$. Damayantî is de hoofdpersoon van de bekende $\mathrm{Nal}$ a-episode in het Ma hâbhârata.

J. fol. a. 5, r. 1: Twașṭ̂a prajâpatir hy âsîd dewaçreșţho mahâtapâh,

sa putrâm cetrîçiracam Indrohakâlaș̣jat.

S. 229: .... sa putram wai Triçirasam Indradrohât kilâș̣jat.

J. ngûnî ring âsîtkâla bhațâra Twașțâ Prajâpati manghanâkèn tapa, makahetu îrșyâ nira ri sang hyang Indra, masamâhita ta sira, mijil ta ng anak sake jñâna nira, daitya si Triçirah rakwa ngaranya: "Vroeger in ouden tijd verrichtte god Twaṣțâ, de

' Deze episode van het Mahâbhârata heet Jațâsurawadha. Zie Wa naparwa, vers $11451 \longrightarrow 11523$ der Calcutta-editie.

2 Zie pag. $23-41$ van mijne nitgave van het O.Jav. Wirâtaparwa.

Dl. 69 , 
Schepper, ascese; uit afgunst op god Indra, concentreerde hij zijne gedachten en uit zijne mijmering ontstond een zoon, die de daemon Triçirah werd genoemd.»

Hier begint de mythe van Nahuṣa, die uitvoerig behandeld is door prof. Speyer in de Actes du $6^{\text {e }}$ congrès international des Orientalistes, section aryenne, p. $81-121$.

J. fol. 6 , r. 2. Tatạ̣ prabhṛti lokasya j̣̣mbhikâ prânasamçritah $=\mathrm{S} .283 b \ldots$ samçritâ.

J. irikâ ta tambe ning rât kabeh yatna megöng prâṇa ri kâla ning angwab: "dat was het begin ervan, dat de geheele wereld trachtte den adem in te houden tijdens het gapen.»

J. fol. 6, r. 4 . Twam prasus sarwwadewânâm twam hi dewa sahadewam,

twam ya sarwwam idang kṛtam sarwwadewanamaskṛtam.

S. 298: twam prabhụ .... twayâ sarwwam idam tatam, twam hi dewo mahâdewah sarwwalokanamaskṛtah.

Dit Sanskrtt-vers is niet vertaald in den Oudjavaanschen tekst.

J. fol. a. 7, r. 3: Sak(h)yam bhawatu te Wṛtra Çakreṇa saha nityadâ,

awâpsyasi suk(h)am twañca Gakralokamwapunkalân= S. $309 b$ en $310 a:$... Çakralokâmç ca çâçwatân.

J. Samitrâ ta kita lâwan sang hyang Indra nityasa, marya werâ paḍâsiha, umuktya ng swarggalokawibhâwa: "sluit vriendschap met god Indra voor altijd, dan zal uwe vijandschap ophouden en zult gij elkaar liefhebben, en zult gij de macht van de hemelwereld genieten.»

J. fol. a. 7 , r. 4: Na çuşkeṇa na candreṇa na sâstrana na bajreṇa,

nasmanenâwa dâruṇa na diwa na niçam tadâ.

S. 320: .... cârdreṇa nâçmanâ na ca dâruṇâ, na çastreṇa na câstreṇa na diwâ na tathâ niçi.

J. tan wastw acat matyana nghulun, tan ajer, tan ing watu, tan kayu-kayu, tan sañjata, tan bajra, tan pějaheng rahineng wěngi: "geen droog voorwerp zal mij dooden, geen vloeibaar voorwerp, geen steen, geen hout, geen wapen, geen bliksemschicht, ik zal niet 's nachts en niet overdag sterven.» 
In de O.-Jav. vertaling leze men asat in plaats van acat, want het is de vertaling van Skr. çușka (droog).

J. fol. 8, r. 2: Indrasỹa mahișî dewî̀ kasmân mânopatiṣṭati,

aham Indrâstrî̀ dewinam lokanañcataweçwarah.

S. 359: ... mâm no patiṣthati, aham Indro'smi dewânâm lokânâñca tatheçwarah.

J. taha strî sang hyang Indra kěteka dewî Çacî, apa tika tan kabhukti de ni nghulun? Nghulun prasiddha Indra pagěh pinakaprabhunta: "de gemalin van god Indra, dewî Çacî, waarom is die niet door mij tot vrouw genomen? Ik ben toch blijkbaar Indra en vast als uw vorst aangesteld.»

J. fol. 10 , r. 1: Icchâmi twâm aham jñanam் ka twam wruhi maranane $=S .429 b: \ldots$ jñâtum kâ twam brûhi warânane.

J. Sâjñâ mahâdewî kamung dewatâ, angapa ta kita kâsihana nghulun warahěn ahyun wruha nghulun ri kita: "met uw verlof, godin, hoe zijt gij genoemd, deel mij dit mede, ik wensch u te leeren kennen.»

De vertaling van "angapa ta kita kâsihana» door: "hoe zijt gij genoemd» steunt op den Skr.-tekst, waar eenvoudig staat: «ik wensch u te leeren kennen, zeg mij, wie gij zijt, o schoone.»

J fol. a, 12, r. 1: Adbhyo'gniḥ brâhmâta kṣatrị̣ açmato laham utwitwam,

tewâm sârwwagatah teja ḥ swasa yonisu çasyati.

S. 482: .... 'gnir brahmataḥ kṣatram açmano loham utthitam,

teṣâm sarwwatragan tejạ̣ swâsu yoniṣu çâmyati.

J. ikang apuy ngaranya ring wwai sangkâ nikâ ngûni, mangkana ng kṣatriya, brâhmaṇa pinakamûlasangkânya, ikang wěsi wungkal sangkâ nika n hana, ikâ ta kabeh, tan apilih kawĕnang nikâ kaçaktin ikâ, yapwan ri sangkânya paranya, pặ̣m juga tanpasâra: "het vuur is vroeger uit het water ontstaan, evenzoo hebben de kṣatriya's hun ontstaan en oorsprong te danken aan de Brahmanen, het ijzer is uit steen ontstaan; de macht van dat alles, onverschillig wat, wordt overwonnen, wanneer het naar zijn oorsprong gaat, dan wordt het uitgedoofd en krachteloos. 
J. fol. a, 12, r. 3: Swayoni bhajate sârwwam் wiçaswâpo' wiçangkâtah $=$ S. $490 a$ : swayonim bhajate sarwwo wiçaswâpo' wiçangkitah.

J. ikang sarwwabhawâ kabeh, tan hana hale nikâ sewitan çaçangkanya, haywa ta kita sandehanta mareng dalěm ning wwai: "alle wezens varen er wel bij, hun plaats van oorsprong te bezoeken, aarzel dus niet, om in het water te gaan.»

In de Oudjav. vertaling staat eigenlijk: het schaadt hen niet (hale = anghala $+i$ ). Çaçangkanya is blijkbaar eene verkeerde schrijfwijze voor sangkanya, misschien ontstaan onder invloed van het woord awiçangkitah (zonder aarzelen) in den Skr.-tekst, wellicht ook eenvoudig eene wanspelling.

J. fol. 12, r. 3: Diṣtyâ bhâwantim pagyami matâram Balasûdana,

diṣtyâ ca Nahuṣongkrașțaḥ dewarâjyât Purandara.

S. $523 a$ en $522 b$ : ... hatârim paçyâmi bhawantam ....

Nahuṣo bhrașțo daiwarâjyât. ....

In den Sanskṛt-tekst is de volgorde dezer beide regels omgekeerd.

J. Sâjñâ hyang Indra, atyanta noha ni nghulun, an ton kita jayaçatru, an tělas umatîkang daitya Triçirah, lâwan ikang daitya si Wṛtta, tan sipi kasukan i nghulun, kunang mangdadyakěn paripûrṇṇa ning inak âmběk, ri denyan bhrașța sangkeng kendran ikang Nahuṣa juga: "met uw verlof, god Indra! Ik ben zeer voldaan, ziende dat gij uwe vijanden overwonnen hebt; dat de daemon Triçirah en de daemon Wṛtra gesneuveld zijn, niet gering is mijne vreugde daarover, doch het schenkt mij volkomen bevrediging, dat ook Nahuṣa uit Indra's hemel verdreven is.

Het begin van deze vertaling is eigenlijk de vertolking van vers $522 a$ van den Skr.-tekst.

J. fol. a, 13, r. 3: Tenâbhûd watatejaçwa niçrîkaçca Çacipate $=$ S. $533 a: \ldots$ dhatatejâçca niḥçrîkaçca mahîpatiḥ.

J. tatan adwa hilang ta lakșminya, dumadak alěk awěněs: "niet lang daarna verdween zijn glans, verminderde en verbleekte».

J. fol. 13, r. 1: Triwiṣțapam prapadyaswa mahi lokan Çacîpate,

jitendriyo jitâmitraḥ stûyamâno maharṣibhị̣. 
S. $538 b$ en $539 a$ : tripiṣṭapam் ... pâhi lokân ... p jitâmitras....

J. tulih ta kamung hyang Indra ri kahyanganta, muwah rakșan ikang swarggaloka, apan iku ya phala ning jitendriya, amoghâlah samusuhta, sanghulun kabeh agya maripûjâ rahadyan sanghulun: "Keer gij terug naar uw hemel, god Indra, bescherm weder de hemelwereld, want dat is de belooning voor het bedwingen uwer zintuigen, immers al uwe vijanden zijn overwonnen, wij allen haasten ons, om u te prijzen.»

J. fol. 13, r. 4: Ekân duḥkam anuprâptam Indraṇami saha bâryyaya,

ajñatawâçaç ca kṛtaḥ çatrụ̣antakam watṛya.

S. 553: Ewam̉ duḥkham . . Indreṇa.. bhâryyayâ, ajñâtawâsaçca . çatrụ̣̂̂̂m badhakângkṣayâ.

J. ndâ nahan ta lwir sang hyang Indra pamanggihakĕn lara magöng, mwang dewî nira, hatur samangkana ta parameçwara, tĕmwakĕn ikâ panusupan ing alas, makahetu çatrubañcaṇa: "Zoo geschiedde het, dat god Indra groot leed ondervond, met zijne gemalin, in overeenstemming met hetgeen Uwe majesteit te beurt viel, die zich in het woud moest verschuilen, ten gevolge van het bedrog van uw vijand.

In de O. Jav. vertaling leze men: an of $n$ pamanggihakĕn. De vertaling van ajñâtawâsa (wiens woonplaats onbekend is) door panusupan ing alas (het binnensluipen in het bosch) is wel wat al te vrij.

J. fol. a, 14, r. 2: Ya idan hiyatah pațet sapretyeha ca modate.

S. 562: (âkhyânam Indrawijayami) ya idam niyatạ̣ pațet,

(dhûtápâpmâ jitaswargaḥ) paratreha ca modate.

J. yâwat tapwa ikang wwang agělem maceking âkyâna Indrawijaya, byakta ya mangguha ng suka ring ihatra paratra: "Als iemand dit verhaal van Indra's overwinning wil lezen, zal hij zeker in deze wereld en hiernamaals geluk ondervinden.»

Hiermede eindigt deze episode en ook dit gedeelte van het Udyogaparwa, dat SEnoDyogaparwa ${ }^{1}$ heet. De eerste 602

1 Vgl. over den inhoud van deze afdeeling van het Udyogaparwa: Holtzmann, Diè neunzehn Bücher des Mahābhārata, II, pag. 103-104. 
verzen van den Sanskrttekst komen dus overeen met iets meer dan 13 folia van de Oudjav. vertaling. Thans volgt het

\section{SAñJAYAYâNAPARWA.}

J. fol. a, 14, r. 3: Dhṛtarâșțraçca Pâṇ̣̣açca sutew ekasya wiçruto,

tayoḥ sâmanan drawị̣am pekâtan nâtra sangçayaḥ.

S. 606:.... Pâṇ̣uç ca sutâw... . wiçrutau, ... sa sa ânarin... paitṛkam....

J. sâjñâ haji, tunggal kěta haji rahadyan sanghulun mwang mahârâja Pâṇ̣u, prasiddhânak ning wwang sasiki, dṛwya rahadyan sanghulun kaliliran kapwa kinalihan ora kinapakṣapâtâkĕn ring swacitta: "Met uw verlof, vorst. Uwe Majesteit staat immers gelijk met vorst Pân ḍ u; het is bekend, dat gij beiden de zonen zijt van één persoon. De door u geërfde bezittingen moeten in tweeën verdeeld worden, daaraan behoeft gij niet te twijfelen in uw hart.»

Het woord kinapakșapâtâkěn in de O. Jav. vertaling (stam pakṣapâta) is hier de vertaling van Skr. sangçayaḥ $=$ twijfel, aarzeling. Op zich zelf beteekent pakșapâta "partijdigheid».

J. fol. 14, r. 1: Na hi te wigraham wîrâh kurwwanti Kurubhih saha,

awinâçena lokasya takṣante Pâṇ ḍawạ̣ swakamin.

S. 616 :... kângkṣante Pâṇ ḍawâh swakam.

J. tan hana jugâhyun sang Pâṇ̣awâpranga lâwan sang Korawa, apan ahyun ikâ swasthâ nikang jagat: De Pâṇ̣awa's verlangen niet te strijden met de Kaurawa's, want zij streven er naar, dat het de wereld wel ga».

J. fol. 15, r. 4: Latà iwa Dhṛtarâștra salaḥ Sañjaya Pâṇ ḍa wâ ḥ,

na latâ warddhate wașu anaçrîtỹa mahâdruma.

S. 864: Latâdharmâ Dhârttarâṣṭ̂ậ çâlâh.... jâtu mahâdrumam anâçritâ.

J. Sang Korawa kângkěn udwad, sang Pâṇ̣awa sâkṣât çâlawṛkṣa, tapwa rambat ta ring wṛkṣa ikang udwad, toh ring kapana tikang wṛdya sulurnya: "De Kaurawa's zijn te beschouwen als een woekerplant, de Pạṇ̣awa's als een çâlaboom. Als een woekerplant niet tegen een boom opklimt, hoe zouden dan hare loten kunnen groeien? 
In den Skr.tekst staat in plaats van deze vraag: geen woekerplant groeit ooit zonder zich te slingeren om een grooten boom.

Op fol. 16 van de O. J. vertaling begint reeds het Prajâgaraparwa. De 367 verzen van den Skr.-tekst van het Sañjayayânaparwa komen overeen met $2 \frac{1}{2}$ palmbladen der $O$. Jav. vertaling. ${ }^{1}$

\section{PRAJâGARAPARWA.}

J. fol. 16, r. 4: Abhiyuktam balawatâ durbbalami hînasâdhanam ,

hṛtaswang kâminañ coram awisanti prajâgaram.

S. 983: .... h ḥ̣taswam kâminam̉ cauram âwiçanti prajâgarâh.

J. Samangkâ lwir ning tar kěneng turû: mawirodha lâwan wwang mahâçakti, mwang malara kunang, wwang daridra, wwang kelang-ilangan dṛwya, ya tan mangkana sẹ̣̣eng mapahyunan, maling kunang, salwir nikâ tar kěneng turû: "Aldus zijn de personen, die niet kunnen slapen: zij die in strijd zijn met machtigen, en zieken en armen en lieden, wier bezittingen gestolen zijn, of anders lieden, die verliefd zijn, en dieven, zij allen kunnen niet slapen.»

De woorden: "ya tan mangkana sẹděng mapahỵunan» zijn mij niet duidelijk. $\mathrm{Zij}$ bevatten eene vertaling van Skr. kâmina ṁ (minnaar).

J. fol. a. 17, r. 3: Niṣewate praçântani nindatani na sewate,

anâștikam çaddhadhânam etat paṇditalakṣaṇam.

S. $991: . .$. praçastâni ninditâni...., anâstiḳạ çraddadhâna....

J. gumawayakna prasiddha kinonakěn ing çâstra, tar gawạ̣a wastu kinelikan, tan pakâmběka ng nâstika, makângěn-angěna karuṇika, yekâ lakṣaṇa ning pạ̣dita ngaranya: "verricht hetgeen stellig wordt voorgeschreven in de geschriften, verricht geen dingen, die afgekeurd worden, wees niet atheïstisch gezind, doch medelijdend, dat zijn de kenteekenen van een wijze.»

Alle vormen, die in de O.-Jav. vertaling in den Conjunctief of Jussief staan, hebben in den Skr.-tekst den Indicatief-vorm. Wij zouden ze het best vertalen door een Infinitief.

1 Zie over den inhoud van het Sañayayânaparwa Holtzmann o, c. p. $104-106$. 
J. fol. a, 17 , r. 4 : Na hṛṣyaty âtmasammanaḥ nâwamâne pyay anata,

Gânggo hrada bhawakṣobhyah yạ̣ sa pạ̣dita ucyate. S. 996: ....sammâne....na tapyate,.... iwâkṣobhyo. ..

J. tan agiranga yan hanângastawa, tan alarâ yan hanâñale, kadi lwir ni wwe ning Ganggâ tapwa tar kěneng lětuh lwir ning pinaṇdita mangkana: "verheug u niet, wanneer er iemand is, die u prijst, bedroef $u$ niet, als er iemand is, die $u$ minacht, evenals het water van den Ganges niet verontreinigd kan worden, zoo is het gedrag van een wijze.»

De O.-Jav. vertaling tar kěnang lětuh (niet vatbaar voor verontreiniging) is onjuist. In den Skr.-tekst staat hier akșobhya (onwrikbaar).

J. fol. 17, r. 1: Çrutam prajñânugam yasya prajñâ yasya çrutânugâ,

asambhinnâryyama ryyâda mạ pạ ḍitakyam labheta saḥ.

S. 999: .... prajñâ caiwa ...., asambhinnâryyamaryyàdaḥ pạ̣ditâkhyâm ....

J. hana wwang sawawa ni buddhinya pinakâjinya, sawawa nikâjinya pinakabuddhinya, gěgönya ta mâryyada sang sajjana, yekâ wastu sinenggah paṇdita: "iemand, wiens leer in overeenstemming is met zijn verstand en wiens verstand in overeenstemming is met zijn leer, die zich houdt aan de leefregels van goede menschen, die wordt met recht een wijze genoemd.»

J. fol. 17, r. 2: Açrutaç ca samunâddhâh daridraç ca mahâtmanâh,

adharççakârmmane prepsuḥ mûḍha ity ucyate wudheḥ.

S. 1000 :...s samunnaddho .... mahâmanâh, arthâm ç câkarmmaṇâ prepsur .... budhaiḥ.

J. hanâhangkâra tar wruh angaji, hana daridra makâmběk wîra, hana tan ahyun ri phala tan mahyuna damělnya, yekâ prasiddha mûḍha ling sang wruh: "er zijn zelfzuchtige lieden, die niet bekend zijn met de geschriften, er zijn armen, die een heldhaftige inborst hebben, er zijn er, die geen begeerte koesteren naar belooning en die niet willen werken, dat zijn blijkbaar dwazen, zeggen de wijzen.» Onmiddellijk daarop volgt:

J. fol. 17, r. 2: A kâmân tamânati yaḥ kamyanañ ca paridwișan,

balawânkañca ye tașți tam âhu mûḍhacetasan. 
S. 1002: .... kâmayati .... kâmayânân parityajet, balawantañ ca yo dweșți .... âhur mụ̂̂hacetasam.

J. hanâhyun ring wastu kinelikan, tan ahyun ing prasiddha kinahyunan, uminda sang mahâçakti, lwir ning mûḍha tikâ rakwa: er zijn lieden, die behagen scheppen in onaangename zaken, en geen behagen scheppen in algemeen geliefde dingen en die machtigen berispen, dat is de handelwijze van een dwaas. »

In de O.-Jav. vertaling leze men voor uminda: numinda (berispen), daar het de vertaling is van Skr.dweșți (haten).

J. fol. 17 , r. 3: Param kṣapari doṣeṇa warttamânaḥ swayan tathâ,

yaç ca krudhyaty aniçaçca ça tu mûḍhatamo narah.

S. 1007: .... kṣipati .... anîçânaḥ sa ca ...,

J. hana humalâkěn ikang wwang len, dumûșanâkěn ikang prasiddha pinakadoșanya, hana tâgěleng ri tan saka ya wěnang kagělengana ya, mûḍha ta ngaran ing mangkana : "er zijn lieden, die andere menschen voor slecht verklaren en hun de schuld geven van hetgeen blijkbaar hun eigen schuld is, en er zijn lieden, die vertoornd zijn op menschen, die niet verdienen, dat men op hen vertoornd is, die noemt men dwazen.

J. fol. 17, r. 4: Anâhûtạ̣ prawaçati apṛșțo bahu bhâmate,

wiswasâyati mânteṣu mûḍhacetâ narâdhamah.

S. 1006: .... prawiçati ... bhâṣ̣ate, awiçwaste wiçwasiti ....

J. hana mara tan pasangkan sinyang, mwang hana lanâwarah tan tinakwanan, hana ta miçwasâwěrö, pratyeka ning mûḍha ta nâma nikâ: eer zijn lieden, die komen zonder geroepen te zijn, en er zijn lieden, die voortdurend raadgeven zonder dat men hun iets gevraagd heeft, er zijn er, die vertrouwen stellen in dronken lieden, dat heet het toppunt van domheid.»

Hier was in den Skr.-tekst, dien de O.-Jav. vertaler gebruikt heeft, de volgorde der verzen anders dan in de Calcuttauitgave. Dit blijkt ook uit het volgende citaat, dat zich onmiddellijk hierbij aansluit en dat in de Calcutta-uitgave vers 1003 is:

J. fol. a, $17^{1}$, r. 1: Amitram kurute pitram mitra dweșți hinasti ca,

karmma cârasate dṛṣṭam tam âhuh mûḍhacetanam.

${ }^{1}$ In cod, $959 a$ is aan twee opeen volgende palmbladen het nummer 17 gegeven. 
S. 1003: .... mitram mitram் ...., cârabhate duṣțam .... âhur mûḍhacetasam.

J. hana wwang umitra musuhnya, ikang pinakamusuh mitranya, ikang kâryyâhayu tan lâgi tan gawayakěnya, paramârtha ning mûḍha padum nikâ: "er zijn lieden, die hunne vijanden vriendelijk behandelen, die hunne vrienden als vijanden beschouwen, die goede daden gewoonlijk(?) niet verrichten, hun deel is het non plus ultra van domheid.»

De woorden tan lâgi in de O.-Jav. vertaling zijn mij niet duidelijk. Lagi heteekent gewoonlijk "vroeger». In het Skr. staat eenvoudig: en wie een slechte daad verricht.

J. fol. a, 17, r. 3: Bhakṣyottamapraticchannam makṣyo watîsam âyasam,

rupabhite gramasate nânuwandham apekṣate.

S. 1106: .... matsyo waḍiçam .... lobhâbhipâtî grasate ....

J. ikang iwak naya, sahasâ ya umělö iking bibit wěsi, tan katon ikâ dening mangsabhaksya, kewala kâkarṣaṇa deni rûpanya: "de naya-visch slikt haastig een ijzeren hengelhaak in, dien hij niet ziet in zijne gulzigheid, alleen aangetrokken door zijn uiterlijk.»

Welke vischsoort door naya wordt aangeduid, is mij onbekend. In het Skr. staat alleen matsyo (visch). Het laatste gedeelte van de O.-J. vertaling staat niet in den Skr.-tekst, maar is misschien ontstaan uit de verkeerde lezing rupabhite voor lobhâbhipâtî (begeerig er op aanvliegende).

J. fol. a, 17, r. 4. Wanaspatir apatwani phalâni prawinoti yah,

sa nâpnoti rasan tebhyo jiwan tasya winaçyati.

S. 1108: wanaspater apakwâni.... pracinoti... wîjam câsya....

J. hana ta wwang agyâwarĕga, malap wwah ning kayu tapwan matasak, pisaningu tikang rasa kapanggiha denya, haywa tânginak, mara tanpabalik wyâdhi riya, dady anggawa ya kapatin: "er zijn lieden, die zich haasten om zich te verzadigen en nog onrijpe vruchten van boomen plukken. Hoe zouden zij den smaak daarvan genieten? Laten zij niet gerust zijn, dat de ziekte niet tot hen terugkeert, tengevolge waarvan zij sterven,» 
J. fol. 17, r. 1: Yathâ madhu samadhate rakṣan puṣpâni sadpaḍa,

tadwad arthân manuṣebhyaḥ adidyâd awihininsayâ.

S. $1110: . .$. samâdatte ... șaḍpadah .... manuṣebhya âdadyâd....

J. kadyangga ning bhramara lolya ta ya mapûra sěkar nikang kayu, těka pwa ya ring katuhan, dadi ya mukti madhu paripûrṇna, mangkana ta sang sajjana prabhu alap sakahyun ikang wwang, tan dadi hingsa katrâsa těkap nira: "evenals een bij zich vermaakt met de bloemen der boomen uit te zuigen, tot haar ouderdom toe, zoodat zij volop honig verzamelt, evenzoo neme een goed vorst alles wat hij van de menschen verlangt, zoodat zij niet vreezen, door hem gedeerd te worden.»

Mapûra is hier blijkbaar de vertaling van madhu samâdatte (honig verzamelen) in den Skr. tekst.

J. fol. 17, r. 2: Puṣpâ puṣpam wicidwiyat mûle cedam wiwarjjayet,

halâkara iwârâme na yatanggârakarakaḥ.

S. 1111: puṣpam .... wicinwîta mûlacchedami na kàrayet, mâlâkâra... y ya thânggârakârakaḥ.

J. kadyangga nikang wwang ananěm kěmbang ing taman, sabarinyan pasěkar ikang kěmbang, ya taya n pupu ya, kintu babadenya, denyalambaha, pinet tatan wěnangnya waluya, haywa ta kadi wwang adamęl arěng ring wukir: "evenals iemand, die bloemen plant in een tuin en wanneer de bloemen bloeien, die niet plukt, doch ze uitrukt en ze vertrapt, zoodat zij niet weder kunnen opkomen, handel niet als iemand, die houtskool makt op het gebergte!»

J. fol. 17, r. 3: Yasyeșyâ pariwitteșu wîryye rûpe kulanwayah,

sukasobhagyasatkarah tasya wyadhi narantakah.

S. 1135: Ya îrṣuḥ.... rûpe bîryye kulânwaye, sukhasaubhâgyasatkâre... wy wâdhir anantakạ̣

J. ikang wwang îrșya ring mâs ning wwang waneh, mairyya manon wîryya rûpa kawwangan kunang, athawâ kimburu manon suka kasubhagan, mwang kadadin pinûjâ karikâ, ikang mangkana yeka tan pawyâdhi aměngan ikâ: "iemand, die afgunstig is op goud van andere menschen, en jaloersch bij het zien van dapperheid en schoonheid en nakomelingschap, of afgunstig bij het 
zien van vreugde en geluk en wanneer iemand geprezen wordt, zoo iemand lijdt niet aan eene voorbijgaande ziekte.»

Kawwangan is hier vertaald door nakomelingschap, omdat het de vertolking is van Skr. kulânwaye (voortzetting van het geslacht).

In de O. J. vertaling schijnt tan paamengan "niet voorbijgaand» te beteekenen. In het Skr. staat: diens ziekte is oneindig.

S. fol. a, 18 , r. 1: Atmanamanâyasaç ca titikṣâ dharmanityatâ,

wak cewa guptâ dânañca netany antyeșu bharate

S. 1167: Âtmajñânam anâyâsas..., wâk caiwa.... naitâny antyeṣu Bhârata.

J. haywa tan wruh mawâwaknya; tan kasakitana, manggönga kopasaman, saktâ ring dharmma, tan dangan wuwusa, wěnanga ta gawe weweh, ikâ ta ng ulah mangkana wěnang ikâgawe kadîrgghyâyușan: "weet u goed te gedragen, opdat gij niet gekweld wordt, leg u toe op zachtmoedigheid en op rechtvaardigheid, laten uwe woorden niet lichtvaardig zijn, en geef geschenken. Een dergelijk gedrag is in staat, u een lang leven te verschaffen.»

In het Skr. staat in het begin: leg u toe op zelfkennis. De Oudjav. vertaling heeft hier dus iets anders.

J. fol. a, 18, r. 1: Ajarwwa pratipadaswa wutreșu satatam wibho,

iha kîrttim parâm prâpa pretya swarggam awassyaçiḥ.

S. 1183: Ârjawam pratipadyaswa putreșu.... prâpya.... awâpsyasi.

J. ikang citta běněr alilang, kapwa paḍa těkâmběkâji ri sang Pâṇ̦awa, haywa wineh mawirodha mwang rânak aji sang Korawa, phala nika kapangguh yaçâtiçaya mangke, tan wurung angjanma swargga jěmah: "laat uw gemoed rechtvaardig en rein zijn, zoo zij de gemoedsgesteldheid van den vorst jegens de Pâṇạawa's, laat niet toe, dat zij twisten met uwe kinderen, de Kaurawa's; als belooning, daarvoor zult gij nu grooten roem verwerven, en ongetwijfeld later in den hemel herboren worden.»

In den Sanskṛt-tekst worden de Pâṇạawa's en Kaurawa's niet genoemd, doch staat alleen putreșu (jegens uwe zonen). 
J. fol. a, 18 , r. 3: Dewadṛwyawinaçena brâhmâṇanam paribhâwat,

wedasyotpadhanena ca.

S. $1285 a$; dewadrawyawinâçena en 1286a: brâhmaṇânâm pari wât pariwâdâc ca.

J. kâlapan ing dewaswa, kâlapan ing dṛbya ning brâhmaṇa, mwang kaparibhâwan ing brâhmaṇa, si manayâkěn dewaçâstra kunang, pạ̣a ikâmurugakěn dharmma: "het stelen van de bezittingen der goden en van die der brahmanen en het minachten der brahmanen, of wie de goddelijke boeken vernietigt, dat alles doet de verdiensten, die men zich verworven heeft, te loor gaan.»

Hier loopt het Skr.-vers in den O.Jav. tekst niet af en bovendien wijkt het sterk van de Calcutta-editie af. Zooals men ziet is de O.-Jav. vertaling hier zeer bekort, daar meer dan 100 Skr.verzen zijn overgeslagen.

J. fol. a, 18 , r. 4: Tṛ̣nâni bhûmir ûpakam wâk catûrjji wa paṇta,

satâm etâni geheșu na cchidyante kadanañca.

S. $1293: \ldots$ udakami... caturthî ca sûnṛtâ... no'.... kadâcana.

J. gangan sagitěs, lěmah palungguhana, wwai ni döng, kapat çabda manis tar bañcana, ya tikâ tanpegat nityasa ikâ kapanggih ryy umah sang sajjanâhyun ing dharmma: "een beetje groente; aarde om op te zitten, water van(?), ten vierde zachte, geen verraderlijke woorden, die worden onafgebroken altijd gevonden in het huis van een goed mensch, die streeft naar deugdzaamheid.

J. fol. 18 , r. 2 ; Buddhyâ bhayam praṇudati tamasa windate mahan,

gurusuçrutayâ jñânam çantintyaçena widdhyate.

S. $2311: \ldots$ tapasâ bindate mahat, guruçuçruṣayâ.... çântim yogena bindati.

J. kaprajñan rakwa mangilangakěn lara ngaranya, mârgga ning pinûjâ kinabhaktyan, tapa nimitta ning amanggih jñâna wiçeșa, bhaktya ring guru mârgga ning amanggih kopasaman, si nistṛ̣na juga, haywa ta parameçwarâgöng ț̣ṣnâ ring upabhoga, yatanyan katěmwa çaktijñâna yâmuhara katinggalan ing lara: "wijsheid, zegt men, doet leed verdwiinnen en is de aanleiding, 
dat men geprezen en met eerbied behandeld wordt, ascese is een middel, om voortreffelijke wijsheid te verwerven, eerbied jegens den leeraar is de weg om tot gemoedsrust te komen, evenzoo het vrij zijn van begeerte; laat de vorst niet te veel streven naar genietingen, ten einde macht en kennis te verkrijgen; deze veroorzaakt het verdwijnen van smart.»

J. fol. 18, r. 4: Sulabhâh puruṣah loke satatam priyawakah,

apriyasya tu patyasya waktâ jroka caturlabhâh.

S. $1348: \ldots$ puruṣâ râjan .... priyawâdinaḥ,... pathyasya.... çrotâ ca durlabhah.

J. apan ikang giṇa priyambada, makweh nitya gumuṇakěn ing loka, kunang ikang prasiddhewěh ikang mujarakna tan priyati n pamuhara hita juga, ngûniweh ikang ruměngwa çabda mangkana, paḍewěh nikâ kalih: "want de eigenschap van te vleien, die brengen velen altijd in praktijk in de wereld, doch hetgeen inderdaad moeielijk is, dat is het zeggen van onaangename zaken, die toch nut veroorzaken, en ook het luisteren naar dergelijke woorden, dat is beide even moeielijk.»

Uit de O. J. vertaling blijkt, dat in den Skr.-tekst, dien de vertaler gebruikte, loke stond in plaats van râjan, zooals in de Calcutta-editie.

J. fol. a, 19, r. 1: Yo hi dharmma wyapâçrîtya hitwâ bhartuḥ priyâyenâ,

apriyenyaha pawyâni sa te râjân sahayakah.

S. $1349: \ldots$ dharmam samâçritya .... priyâpriye, apriyâny âha pathyâni tena râjâ sahâyawân.

J. hana wwang kewala gumegwa ng dharmma, tar uningâ ri tan manginakana ring prabhu, wěnang ta yomujarakěn ng apriya, nda hitâwasâna těkapnya, yeka bhukti sahâya ni kadi parameçwara: "er is iemand, die zich alleen aan zijn plicht houdt, zonder er op te letten, dat hij den vorst niet welgevallig zou kunnen zijn, en die zich gerechtigd acht, om onaangename dingen te zeggen, doch die hem ten slotte nuttig zullen zijn, zoo iemand moet tot helper genomen worden door iemand als de vorst.

In de O.-Jav. vertaling leze men: yukti in plaats van bhukti.

J. fol. a, 19, r. 3: Çahyabandhanayartha sahâyâç cârthabandhanâh,

anyonyabandhanah heto winyanyonyam na sidhyatah. 
S. 1371: sahâyabandhanâ hỵ arthâh...., anyonyabandhanâw etau winânyonyam ....

J. Sahâya kěta sumiddhâkěn hana ning mâs, ikang mâs sumiddhâkèn hana ning sahâya, parasparopasarpaṇa wěkasan, ya tapwan tan mangkana, ubhayobhâwa wijil nikâ mene: "vrienden immers bevorderen het verwerven van goud, en goud bevordert het verwerven van vrienden, ten slotte verbinden zij zich onderling. Als dat echter niet het geval is, ontstaat daaruit het niet slagen van beide.

In plaats van ubhayobhâwa in de O. J. vertaling moet men waarschijnlijk ubhayorabhâwa lezen, want het is de vertaling van Skr. na sidhyatah (zij beide slagen niet).

J. fol. a, 19 , r. 4: Na syat wanam ṛte wyaghrat wyâghrâ na syụ ṛte wanât,

wanam hi rakṣyate wyaghraḥ wyâghrân rakṣati kânanam.

S. 1379: Tasmâd.... wỵâghrân.... sỵur ṛte wanami... wyâghrair....

J. çînṇa těka ng alas yan tan hana ng singha, mati singha yan tan hana ng alas, matangnyan mangkana, apan ikang singha rumakșekang alas, ikang alas rumakșekang singha: "het woud wordt immers verwoest, wanneer er geen leeuwen zijn, de leeuwen komen om, wanneer het woud er niet is; de reden hiervan is, dat de leeuwen het woud bewaken en het woud de leeuwen bewaakt.

Het is eigenaardig, dat het woord wyâghra (tijger) in den Skr.-tekst in de O. Jav. vertaling wordt weergegeven door singha (leeuw).

J. fol. 19 , r. 1: Sanniyascati yo wegam uttitam krodhaharșayoh ,

ça çriyo bhajanam râjan yaç capadi na muhyati.

S. 1384: Sanniyacchati... utthitaṁ..., sa... bhâjanam்.... câpatsu....

J. ikâ sang wěnang humerrět gělis ning râgadweșa, sira kinahanan ing lakșmî, mwang ikâ sang kěneng lara tan katěkan lara: «hij, die in staat is de opwelling van hartstocht en haat te bedwingen, hem valt geluk ten deel en wie door leed getroffen wordt, die wordt daardoor niet bereikt.

J. fol. 19 , r. 2 : Widỵaçilâwakew ṛddhan buddhiw ṛddhâç ca Bhârata,

dhanâbhijanawṛddhaç ca nityam mûḍho' wamanyate. 
S. $1431 b$ en $1432 a$ : widyâçîlawayow ṛddhân buddhiw ṛddhâmç ca ..., dhanâbhijâtaw ṛddhâm̧ç ca ....

J. lwir ning katwangana, wwang atuha dening wruhnyângaji, hanâtuha dening çîla yukti, mwang atuha dening wayah juga, hanâtuha dening kaprajñan, hanâtuha dening kasujanmân, ikâ wwang tan atwang ing samangkâ, yekâ mûḍha ngaranya: "de volgende personen zijn vereerenswaardig: lieden, die oud zijn, omdat zij de geschriften kennen, er zijn er, die oud zijn, omdat zij zich passend gedragen, en die slechts oud zijn van leeftijd, er zijn er, die oud zijn wegens hun verstand, anderen weder wegens hun edel geslacht, lieden, die niet op eene dergelijke wijze vereerenswaardig zijn, worden dwazen genoemd.

J, fol. 19', r. 3: Na ça râtro sukam sete sahsârppa iwa weçmani,

ye kâmayati nirdoṣa saḥdoṣa' bhyantaram janam.

S. $1437 b$ en $1438 a: \ldots$ ca râtrau sukham çete sasarpa...., yah kopayati nirdoṣam sadoṣo'....

J. ikâhyun ri doṣa nikâ wwang an taya hetu ni doṣanya, ya tikâ tan enak turûnya ring kulěm, kady aturû ring umah mesi sarppa: "Wie iemand een schuld wil aanwrijven, terwijl er geen oorzaak voor die schuld is, die slaapt 's nachts niet rustig, alsof hij sliep in een huis, gevuld met slangen.»

J. fol. a , 20, r. 1: Yo jâtim anugṛhṇ̂ti daridrân dînam âturam,

sa putrapaçubhị wṛddham yaçaç cakṣayam açnuțe.

S. $1462 b$ en $1463 a$ :... jñâtim .... daridram .... putrapaçubhir wṛddhim çreyaçcânantyam....

J. ikang wwang masih ri kadangnya rakwa, mo daridra kasyasih tuwi kawargganya, ndah inanugrahanya juga enak amběk, ikang wwang mangkana byaktâmanggih kawṛddhyan mwang yaça tanpalwasan rakwa ikâ, ngûniweh anaknya wṛddhi, lâwan wěnang-wěnangnya: "iemand, die zijne verwanten liefheeft, en al is zijne familie arm en deerniswaardig, toch haar gunsten bewijst en welgezind is, zulk een man zal zeker voorspoed en onvergankelijken roem verwerven, en ook zijne kinderen zullen voorspoedig zijn, alsmede zijne huisdieren.»

Uit de O.Jav. vert. yaça tan palwasan (onvergankelijke roem) blijkt, dat inderdaad in den Skr.-tekst, dien de vertaler gebruikte yaçaç câkșayam stond, terwijl de Calcutta-editie 
çreyaç cânantyam heeft. Wěnang-wěnang is door "huisdieren» vertaald, omdat het de vertolking is van paçu in den Skr.-tekst.

J. fol. a, 20 , r. 2: Trimantam jñâtim âsâdỵa yo jñâtir awasiddati,

dagdhawṛkṣam mṛga iwa sâdhanam tasya nindita.

S. $1472 b$ en $1473 a$ : çrîmantam .... awasîdati, digdhahastam .... sa enas .... bindati.

J. hana kadang duḥka mare kadangnya sugih, ndatan hana lihat nikang pinaran, magawe ta ya larâmběk irikang mara, ikâ ta kadang sugih tan hana sihnya pinaran, nininda mâs nikâ dening umara, kadyangga ning alas gěsĕng kayunya, nininda ikâ dening mṛga: "er is een arme bloedverwant, die gaat naar zijn rijken verwant, doch niet opgemerkt wordt door hem, tot wien hij gaat, dit veroorzaakt dengene, die gaat, teleurstelling, en de rijke bloedverwant, de liefdelooze, tot wien hij gaat, diens goud wordt versmaad door hem die gaat, evenals een woud, welks boomen verbrand zijn, versmaad wordt door het wild. »

Dat dagdhawṛkṣam vertaald wordt door: gěsĕng kayunya bewijst, dat deze lezing inderdaad in den Skr.-tekst stond, dien de O.-J. vertaler gebruikte. In de Calcutta-editie staat: digdhahastam.

J. fol. a, 20 ; r. 4 : Yat sukami sewamâno 'pi dharmmârthanyan na hîyate,

kaman tad uwaceweta na mûḍhabratam âcaret.

S. 1506: .... sukham .... dharmmârtỉâbhyâm ....,kâk mam ....u upaseweta...

J. ikâ sang amanggih inak âmběk, haywa juga surud sangka ring dharmma lâwan artha, makaphala tan luputa ning kâma kabhuktya de nira, haywa ginuṇâkěn brata ning hînabuddhi: "wie gemoedsrust geniet, moet toch niet afwijken van zijn plicht en zijn voordeel, opdat het geluk, dat hij geniet, niet verloren ga, laat hij niet de gelofte van domme lieden in praktijk brengen.»

J. fol. 20 , r. 1. Agnihotraphalâ wedâh brataçîlâphala ỉ çruta m,

ratiputraphalâ darạ̣ dattabhûktiphalan dhanam. D1. 69 
S. $1511 b$ en $1512 a$ : .... çîlaw ṛttaphalam .... nârî dattabhuktaphalam ....

J. yajñakâryya rakwa kawangunan weda yan tinamâkěn, brata mwang çîla yukti phala ning çâstra, sanggama lâwan anak phala ning strî hinanâkěn, kunang phala ning mâs pirak, yan pinakadriwya, bhukti mwang paweweha: "het brengen van offers, zegt men, leidt tot den weda, wanneer men er ervaren in is, geloften en een passend gedrag is de belooning der geschriften, coitus en kinderen zijn het loon van eene vrouw, waarom zij geboren wordt, doch goud en zilver dragen vrucht, wanneer degene, die het bezit, ervan geniet en het wegschenkt.»

Blijkens de O.-Jav. vertaling heeft inderdaad in den Skr.-tekst, dien de O.J. vertaler gebruikte, gestaan: brataçîlaphalam, terwijl de Calcutta-editie çîlawṛttaphalam heeft.

J. fol. 20 , r. 2: Abhiwâdanaçîlasya nityam wṛdopasewinah,

catwâri miccapesuna kîrttir âyur yaço balam.

S. $1520 b$ en $1521 a$ : .... wr d dhopasewinah, .... samprawarddhante....

J. apan ikâ makaswabhâwa stuti, lana tarmolah ing wwang atuha, yekâ pat dṛwyanya paripûrṇna, ndya tang pat ngaranỵa, kastawan, hurip aglis, yaça mwang kaçaktin, mangkana pinakalabhânya: "want wie van nature geprezen wordt en altijd in de nabijheid van oude lieden is, die heeft vier dingen volkomen, n.l. lof, een lang leven, roem en macht, dat is hetgeen hij verkrijgt.

J. fol. 20, r. 3: Anṛtañca samutkarṣe râjagâmi ca peçunâm ,

catwari samprawadante sâman tat brahmahatyayâ.

S. 1534: Anṛte ca samutkarṣo .... paiçunam̉, guroç câlîkanirbandhạ samâni ....

J. hana lñok ring wwang irikâ sang lěwih, mwang pamiçuna ring wwang prabhu, lâwan waliwi tan maniwoniwo wwang guru, ikâ ta wwang molah mangkana, paḍa lâwan brahmahatyâ rakwekâ: "er zijn lieden, die liegen jegens hoogerstaanden, en die den vorst lasteren, en die weerspannig zijn en hun leeraar niet gehoorzamen; lieden, die zich zoo gedragen, staan gelijk met Brahmanenmoordenaars, zegt men.»

Uit de O.-Jav. vertaling blijkt, dat de beide eerste woorden 
van den tweeden regel verwisseld zijn met die van vers $1521 a$ (zie boven) en dat de oorspronkelijke lezing ongeveer moet overeengestemd hebben met die der Calcutta-editie.

J. fol. 20, r. 4: Âtmâ nadî Bhârata pûṇyatirtthạ̣ satyonakâ dhṛtikûlâ darmmomaḥ,

tasyâ snâtaḥ prâyati pûnyakarmmah puṇyo hy âtmâ nityam akṣobhya ewa.

S. 1553: .... puṇyatîrthâ satyodakâ .... dayormmiḥ, tasyâm .... pûyate puṇyakarmmâ .... alobha ....

J. ikâ sang hyang âtmâ sira kěta kângkěn lwah, pawitra pwa wway nikanang kasatyan, makatâmběng lěbâmběk, makakâryya tikang kopaçamân, ikang lwah mangkana lwirnya, ngkâ tikâ wwang magawaya karmmâhayu npadyus matîrtha, sang hyang âtmâ pinakapadyusan pih, yatika sira tar kěneng lětuh: "de ziel immers is te vergelijken met eene rivier, die de waarheid tot haar rein water heeft, en die tot oevers heeft een tevreden gemoed, en tot golven gemoedsrust. In eene dergelijke rivier zullen de menschen een goede daad verrichten, door zich daarin te baden, ook de ziel is te beschouwen als eene badplaats, die wordt vrij van onreinheid.

In plaats van makakâryya leze men in de O.-Jav. vertaling: makaryyak, daar het de vertaling is van ûrmmih in den Skr.-tekst.

J. fol. a, 22, r, 1: Dhṛtỵ̂ sisnodarami rakṣet pâṇipâdañca cakṣuṣ̂,

cakșu çrote ca manasâ mano wawañca karmmaṇâ.

S. 1556: .... çiçnodaram ...., cakṣuh çrotre .... wâcañ ca $\ldots .$.

J. ikang wtěng payu pastha rakṣyan ring dhṛti citta, tar wehana sing kahyunya, kunang sâdhana ning mangrakṣa tangan mwang suku, nya ng mata, sâdhana ning rumakṣa mata lawan talinga, nya ng manah, sâdhana ning rumakșa ng manah mwang çabda, nya ng ulah: "den buik en de geslachtsdeelen moet men bewaken met standvastigheid, men moet ze niet in alles wat zij wenschen toegeven, doch het middel om handen en voeten te bewaken, dat zijn de oogen, het middel om de oogen en ooren te bewaken, is de geest, en het middel om den geest te bewaker, dat zijn (goede) handelingen. 
Hier eindigt het Prajâgaraparwa. ${ }^{1}$ De 593 verzen van den Skr.-tekst beantwoorden aan 6 folia der O.-Jav. vertaling.

\section{SANATSUJâTAPARWA.}

J. fol. a, 22, r. 4: Mṛtyur nâstiti (= S. 1566b), J. tan hana kěta mṛtyu ngaranya: "immers hetgeen men "dood» noemt, bestaat niet.»

Deze woorden van Sanatsujâta haalt Widura aan in het begin van het Sanatsujâtaparwa.

J. fol. a, 23, r. 4: Yeṣ̂n darmmeșu wisparddhâ bale walamatam api,

te brâhmaṇaḥ lětaḥ pretya brahmaloke prakaçate.

S. 1602 .... wrate 'tha.... bala watâm iwa,... brâhmaṇâ itaḥ.... prakâçakâh.

J. ikâ sang ahurhuran agawe dharmma, yadyapin mahâçakti tuwi, ndah dharmma tah ginawe nire ngûni, sira tikâ makajanma ng brâhmaṇa, sobhâgya ring ihatra paratra: "hij die er de voorkeur aan geeft, zich op deugd toe te leggen en al is hij ook machtig, zich toch daaraan wijdt, die wordt herboren als Brahmaan en is gelukkig in deze wereld en hiernamaals».

Uit de O.Jav. vertaling blijkt, dat in den Skr. tekst, dien de vertaler gebruikte, dharmmeșu en api stond, terwijl de Calcutta-editie wrate' tha en iwa heeft.

J. fol. 23, r. 1: Nismin loke tapas taptam phalam anyatra drçyate,

brâhmaṇ̂nâm ime lokaḥ wṛddhe tapasi samyatam.

S. 1630: asmil... bhujyate,... lokâ dhâtwe.... tișțhatâm.

J. ikang tapa tîbra dening gumawayakěn mangke, hělěm ikân kabhukti phalanya, hana pwa makajanma ng brâhmaṇa mangke, tîbra deny angěnâkěn tapa kalingan ikâ ngûni: "het verrichten van strenge ascese nu, daarvan wordt later de belooning genoten; sommigen zijn nu als Brahmanen geboren, omdat zij vroeger strenge ascesce hebben verricht.»

J. fol. 23, r. 2: Krodhah kâmo lobhamohat bhibhatsa' kṛpasûyâ manasoka spṛhâ ca,

îrṣyâ jugusu ca manaṣyaḥ doṣậ warjyâh pậ̣ dwadaçate nareṇa.

1 Zie over den inhoud van dit parwa: Holtzmann, o.c. p. 106-107. 
S. 1636:... lobhamohau widhitsâ' kṛpâsûye mânaçokau.... jugupsâ.... manuṣyadoṣâ... sadâ dwâdaçaite narânâm.

J. göng krodha, göng râga, lobha, moha, hingsaka, göng asih, göng piçuna, ahangkâra, kingking, tṛ̣ṇa , îrṣya, paranindâ, nâhan tang doṣa hana ring janma mânuṣa, rwâwělas kwehnya, ya tikâ tinggalakna de sang ahyun ring tapa: "hevige toorn, hevige hartstocht, begeerte, verblinding, het deren van levende wezens, hevige liefde, kwaadspreken, zelfzucht, verdriet, verlangen, ijverzucht, het berispen van anderen, dat zijn de gebreken, die zijn in het menschengeslacht, ten getale van twaalf, die moeten vermeden worden door hem, die streeft naar ascese."

J. fol. a, 24, r. 1: Etasya wedasyajñanât wedâs te bahayo bhâwet,

tasyasyekasya râjendra satye kâccid asisthîtah.

S. 1663: Ekasya waidyasyâjñânâd.... bahawạh kṛtâh, satyasyaikasya.... kaçcid awasthitah.

J. tunggal tapwa kawruhanta weda, tamolahakna ikang weda sakawruhanta, yâwat margkana, ndâ nyan hana satyanta rikang weda siki satya witaya, phala nikâ kinawruhan.

Deze O. Jav. vertaling is mij niet duidelijk. De lezing wedyas ya is echter beter dan die der Calcutta-uitgave. Onmiddellijk daarop volgt:

Dânamadhyayanam yajñạ lobhâste tatra warttate = S. $1664 b$ :... yajño lobhâd etat prawarttate.

J. saphala ning jñaçâstra kapanggih denta: "alle belooningen van de offerwetenschap worden door u verkregen.»

Met jñaçâstra in de O.J. vertaling is blijkens den Skr.-tekst yajñaçâstra bedoeld.

J. fol. a, 24, r. 2: Nâraṇyawaçanac cewa munir bhawati saswatah,

sirâkṣaṇan tu wedanam sa muniḥ çreșțah ucyate.

S. 1680: Maunân na munir bhawati nâraṇyawasanân munih,

swalakṣanan tu yo weda sa munih çreșţa ucyate.

J. tan si munggw ing alas kěteka sěnggahěn wiku, apa pwa ya, sang wěnang karakșan ing weda tuwi, sira lěwih kabhujanggan ira paramârtha: "niet hem, die in het woud woont immers moet men voor een bedelmonnik houden, doch wie beschermd wordt door den weda, diens geleerdheid is voortreffelijk. 
Blijkbaar heeft in het hs., dat de O. Jav. vertaler gebruikte, gestaan: Nârạ̣ya yasanâc caiwa munir bhawati çâçwatah. In den tweeden regel heeft de vertaler raksaṇa gelezen in plaats van lakṣaṇa. Onmiddelijk daarop volyt:

sarwwatanam wyakarạnat wiryâkarạ̣a ucyate, pratyakṣadarçça lokânâm sarwwadarççî bhâwet narah.

S. 1681a: Sarwwârthânâm wyâkarạ̣âd waị̂akarạ̣a.... en 1682a: pratyakṣadarççî... bhawen ....

J. sang wruh ing kajaran ing sarwwârtha, sira waị̂akarạ̣a ngaran ira, sang pratyakșa de nira tumon sarwwaloka, sira sarwwadarççî ngaran ira: "wie de verklaring van alle zaken weet, die heet waiyâkarạ̣a, en wie met eigen oogen de geheele wereld ziet, die heet sarwwadarççî (allesziend).

De O. Jav. vertaling van het Sanatsujâta parwa ${ }^{1}$ loopt tot fol. 24 , r. 1 en bevat dus $2 \frac{1}{2}$ folia tegen 225 verzen in den Skr.-tekst.

\section{YâNASANDHIPARWA.}

De O. Jav. vertaling van dit parwa begint op fol. 24, r. 1 met: atha masowe nirângucap-ucap, bhawișyati lunghâ tikang kulěm enz.: "nadat zij langen tijd gepraat hadden, was de nacht verstreken. Dit komt overeen met:

S. 1791: Ewami Sanatsujâtena Widurẹ̣a ca dhîmatâ, sârddham kathayato râjñaḥ sâ wyatîyâya çarwwarî.

Van dit parwa is in de O.J. vertaling veel overgeslagen, want op fol. 25 , r. 1 is aangehaald:

Nâranâraỵạa ceto lokalokami sâmasthîto, dûrjjâto swena tapaso mahâsatwaparakrama.

S. 1924: Naranârâyạ̣âw etau lokâllokam samasthitau, ûrjjitau .. tapasâ mahâsatwaparâkramau.

J. Sâjñâ hỵang Naranârâyaṇa ngaran sira kalih, matapa ring gunung Lokaloka, ring lambung sang hỵang Mahâmeru, nora maḍana rasika ring kawî̀yyan lâwan kaçaktin: "met uw verlof, Nara en Nârâyạ̣a, zij beiden verrichtten ascese op den berg Lokaloka, aan de helling van den Mahâmeru, ongeëvenaard in dapperheid en macht.»

J. fol. 25, r. 4: Nara Indrasya sanggrama hatwâmitrâm parantạpạ̣,

Poloman Kàlakañjâçca sahaçrạ̣am çatâni ca.

1 Vgl. wat den inhoud betreft Holtzmann, o. c. p. 107-109. 
S. 1930:.... sanggrâme.... çatrûn.... Paulomân Kâlakañjâmç ca sahasrâṇi....

J. sang hyang Narâmějahi musuh sang hyang Indra ngkâ ring palagan, makâdi Poloma Kâlakañja, ngûniweh ikang detyaa samânya, satusiwu kweh nikâ: "Nara doodde de vijanden van god Indra daar op het slagveld, te beginnen met Pauloma en Kâlakañja, en de gewone daitya's, ten getale van honderdduizend.»

J. fol. a, 26, r. 2: Ewam èto mahâwîryyo te paçyata sâmagato =S. 1934b: .... etau mahâbîryyau tau .... samâgatau.

J. sang Nârâyaṇa samangkana kamahâtmyan ira, rasika tinghalana sẹ̣enng paḍa hana: "zoo was de voortreffelijkheid van Nârâyaṇa, ziet daarnaar, terwijl zij er beiden zijn.»

Hier vergeet de O.-Jav. vertaler, dat er behalve van Nârâyaṇa (Kṛna) ook sprake is van Arjjuna, zooals uit vers $1935 a$ van den Skr.-tekst blijkt. Dit vers wordt aangehaald:

J. fol. a, 26, r. 3: Wasudewârjjuno wiro sâmaweto mahabalo= Wâsudewârjjunau bîrau samawetau mahâbalau (in den Skr.-tekst staat: mahârathau).

J. Yekâ mangaran Kṛ̣̣̣ârijjuna hatur mahâçakti: Dezen heetten Kṛṣna en Arjjuna en waren beiden zeer machtig.

J. fol. a, 27, r. 4: Patitah mùrccato bhuwih $=$ S. $1978 a$ : (Sañjayo'yam mahârâja) mûrcchitạ̣ patito bhuwi.

J. mûrcca ta sira wěkasan kapati ri palungguhan: "ten slotte viel hij in zwijm op zijne zitplaats.

J. fol. 27 , r. 3 : Jâgarmmi râtriyaḥ sarwwâ dîrgghyam uṣnañ ca niçcasan,

sito Wṛkodarât ataḥ singhâ paçur iwacalah.

S. 2020: .... râtrayah .... dîrgham .... niḥçwasan, bhîto .... tâta siminât .... iwâparah.

J. ikâ matang yan tan paturû pirang râtri mangke, singgih angga nikâ, mahosan umhah tan pântara, deni takutku ri sang W ̣̣kodara hetu nikâ, kadi lěmbw awědi ring singha: «dit is de reden, dat ik nu vele nachten niet geslapen heb, waarlijk ik wil dat niet doen, ik zucht en klaag onophoudelijk, uit vrees voor Wrikodara, evenals een rund bevreesd is voor een leeuw.

J. fol, a, 28, r. 1: Manasâ'ham praçyami brahmadaṇ- 
ḍam iwodyate $=\mathrm{S} .2025 b: \ldots$ prapaçyâmi .... iwotthitam.

J. yan kângěn-angěn katara ni gadânya kadi brahmadạ̣ḍa kahiḍepanya: "als ik er over nadenk, verschijnt voor mij zijn knots, die te vergelijken is met Brahmâ's staf.»

J. fol. a, 28, r. 1: Bhîmasenamayârjjuna tatân manda titarsapah,

apâram aplawagặ̣p katham gakșyanti me suta.

S. 2043a: Bhîmasenamayam durgam tâta mandâs titîrṣawa h.

S. 2042b: .... a plawâgâdham en S. $2042 a$ : ... çakṣyanti... sutâh.

J. Nihan ta paḍanya waneh, sâkṣât tasik durggama juga ng Wṛkodara, bișți tan pa těpi norana parahu wěnang měntasana ya, ike yânaku Korawa çata wwang apunggung hatěn uměntasa, ri kapana tikâ těka ri donya: "dit is eene andere vergelijking: Wṛkodara is als eene moeielijk te bevaren zee, zonder oevers, die geen schip kan oversteken. Hoe zouden mijne zonen, de honderd Kaurawa's, die zoo dom zijn, hun doel kunnen bereiken?»

J. fol. a. 28 , r. 3: Kạ̣ tiṣțed agrataḥ pumân $=$ S. $2062 a$ : (bâhubhyâm yudhyamânasya) kas tiṣṭhed...

J. syapa ya çûra wěnang munggwe harĕp nikâ: "wie is de held, in staat, om zich voor hem te bevinden?»

J. fol. a, 28, r. 4: Kin tat kuryan katam kuyyam kwa nu gañcapi Sañjaya.

S. 2081b: kim na kuryyâm katham kuryyâm.... gacchâmi....

J. apa tiki upâyangkwa, ndya ikâ upâyangkwa: "wat zal ik doen en hoe zal ik het doen?»

De laatste woorden: Kwa nu gacchâmi Sañjaya (waarheen toch zal ik gaan, Sañjaya) zijn niet in het O.Jav. vertaald.

J. fol. 28 , r. 2 : Idañ jâta idam labdam் $=$ S. $2125 a$ : Idan் jitam.... labdham.

J. ikâ sawuwus ginawe ngûni, yekâ kapangguh phalanya mangke: "al wat vroeger is verricht, daarvoor wordt nu de belooning verkregen. 
In de O.Jav. vertaling leze men: sahuwus in plaats van sawuwus.

J. fol. a, 30, r. 2: Yawadwî sûryyâtikṣṇoyam baddhyed abhrena Marima,

tadepya paridyajyaçca bhûmi nạ̣ Pâṇ̣awân prati.

S. 2312: Yâwaddhi çûcyâs tîkṣṇâyâ widhyed agrẹ̣a Mârișa,

tâwad apy aparityâjyam bhûmer...

J. salawas sang hyang Âditya n sumuluhi bhûmitala ta pwa, samangkâ lawasangkwa tar wehaknekang prthiwîrâjya rikang Pâṇ̣awa: "zoolang als de zon het aardrijk verlicht, zoo lang zal ik de heerschappij over de aarde niet aan de Pâṇ̣awa's geven.»

Uit de O.J. vertaling zou men opmaken, dat de O.J. vertaler inderdaad in het door hem gebruikte hs. sûryyas gelezen heeft, terwijl de Calcutta-tekst çûcyâs heeft.

J. fol. 30 , r. 1: Kṣamâ dhṛtir ahisa ca samatâ satyam ârjjawam,

indirawajayo dhairỵam mârddawam har acâpalam.

S. 2443: .... ahiminân...., indrị̣âbhijayo.... hrîr...

J. kěla ning sukaduḥka, manah lěbâ, tar hingsaka, kasanmatan, kasatyan, tan hilya, kalahan ing pañcendriya, kadhîran, kamahârddikân, göng ning irang, tañ câpala: "het verdragen van vreugde en leed, opgeruimdheid, het niet deren van levende wezens, gelijkmoedigheid, waarheidlievendheid, zich niet laten meeslepen(?), het bedwingen der vijf zintuigen, standvastigheid, edelaardigheid, groote schaamte, niet lichtzinnig zijn.»

J. fol. 30 , r. 2 : Suw ṛttaḥ çîlasampannaḥ prasannatmatmapat wudhah.

prâpyeha loke sanmânam sugatam pratya gaccati.

S. $2447 b: \ldots$ prasannâtmâtmawid ....,

S. $2448 a \ldots$ sugatim pretya gacchati.

J. Ikang wwang ahayu salwir ning kâryyanya, wruh ta ring çîla yukti, mabungah ta hatinya, wruh ta mawâwaknya, ya tikâ paramârtha wruh ngaranya, kinatwangan pinûjâ hana ngke ring loka, ring janmântara tuwi, salwirning hayu pinangguhakěnya: "iemand, wiens daden alle goed zijn, die zich goed weet te gedragen en verheugd is van hart, die weet, hoe hij zich 
moet houden, die heet een volmaakte wijze en wordt vereerd en geprezen in deze wereld en zelfs in andere geboorten ondervindt hij al wat goed is.»

J. fol. 30 , r. 4: Çakunînâm yathâkâçe padan newa pradrçyate,

ewam prajñân atṛptasya muner watma na widyate.

S. $2452 b$ en $2453 a$ : ... iwâkâçe .... naiwopalabhyate, .... wartma na dṛçyate.

J. tapak ing manuk anglayang tan katon mara jati nikâ, hatur samangka tikang pinakaparijñâna sang wiku, trus wruh nira ring sarwwatatwa: "het spoor van een vliegenden vogel, daarvan is de aard onzichtbaar, evenzoo is het met de kennis van den bedelmonnik, zijn verstand doordringt alle zaken.»

J. fol. a, 31, r. 2: Wicitra idam haçcayyam mṛ̂apa wratyabhași me,

plawamano hi kâcaro padâtir anudhâwasi.

S. 2460: Wicitram .... âçcaryyam mṛahan pratibhâti ...., plawamânau .... khacarau.....

J. taha kamung çawara, kapuhan nghulun deni wěkasta, an pangusî manuk manglayang ring âkâça, kita haneng sor manapak lěmah, ring kapana tikan kasiddhâ saprayojananta: "o gij jager, ik ben verbaasd over uwe handelwijze, dat gij eẹn vogel achtervolgt, die in de lucht vliegt, terwijl gij beneden den grond betreedt. Hoe zult gij uw doel bereiken?»

J. fol. a, 31, r. 3: Pâçam ekam ubhâw eto sahito harato mama,

yatra we wipatiṣyete tatra me waṣa çeșyatah.

S. $2461: \ldots$ etau sahitau..., .... wai wiwadiṣyete.... waçam eșyatah.

J. a mpu kaki, tunggal kapwa tali pinasang ni nghulun, bhedanya hulukâla mangalih rwang siki pwekang manuk parěng tumawanakěn $y a$, ring kapana tikâ tan tibâ měne, yapwan jâtinya dudû ta mwang rowangnya, tibâ pwa ya, irikâ ta nghulun malapa ya: "o grootvader! ik heb één strik gespannen; anders dan in vroeger tijd zijn.de twee vogels naar elders gegaan en hebben tegelijk de strik mede weggevoerd; wanneer zij echter werkelijk met elkaar oneens worden, dan vallen zij en dan zal ik ze vangen.» 
J. fol. a, 31, r. 4: Pṛthiwyâm sannipetatuh $=$ S. $2462 b$ : (wigrthya ca sudurbuddhî) ....

J. tibâ ta ya ring lmah: "zij nu vielen op den grond.»

J. fol. 31, r. 1: Etatan te jñayah sarwwe = S. $2464 a$ : ewam ye jñâtayo'rtheșu.

J. Mangkana ta kita kabeh sakutumbâ: "evenzoo gij allen met uwe verwanten.»

Aan het slot van fol. a, 32 eindigt het Yânasandhiparwa. ' Dit bevat in de O.-Jav. redactie 8 folia tegen 799 verzen in den Skr.-tekst.

\section{BHAGAWADYÂNAPARWA.}

J. fol. 32 , r. 4: Çûdrah karoti suçruṣah weșyah wipanawijanah ,

wayam wadhena jîwâmah kapâlam brâhmaṇe wṛtam.

S. 2627: .... çuçrûṣâm waiçyo wipaṇijîwikâm, .... brâhmaṇair ....

J. dharmma ning çûdra ngaranya, si bhakti tutut ya kahuripanya, ikang wwang weçya, si madwal awěli, ya pinakopajîwananya, iking kadi sanghulun kṣatrịa si pějah ring raṇa ya pangan inum ngaranya, yapwan sang brâhmaṇa kapâlîkâ brata nasi pinakopahâra nira: "het is de plicht der Çûdra's, om eerbiedig en gehoorzaam te zijn, dat is hun levensonderhoud, de Waiçya's leven van koopen en verkoopen, lieden zooals wij, Kșatriya's, voor ons is sneuvelen op het slagveld eten en drinken, wat de Brahmanen betreft, die zijn de voornaamsten, hunne gelofte is, te leven van hetgeen zij verkrijgen door bedelen. ^

J. fol. a, 33, r. 2: Sukaḥ praçântah swapitiḥ hitwâ jayaparajayah,

jâtaweras tu puruṣo duḥkam swapiti nityadâ.

S. 2640: Sukhami... swapiti... jayaparâjayau, jâtawairaç ca.... duḥkham ....

J. sukenak aturû sang çânta ngaran ira, sang tan ahyun ring jayaparâjaya, kunang ikang wwang wirodha, yekâ tan enak turûnya: "rustig en lekker slaapt de bedaarde, die niet streeft

1 Vgl, over den inhoud: Holtzmann, o. c. p. 109-111. 
naar overwinning en zegepraal, doch een twistziek mensch, diens slaap is niet rustig." Onmiddellijk daarop volgt:

Nacâpi weram weraṇam kadâcid upaçâmyati, hawiṣ̂a' ghni ghatha Kṛṣna bhûya ewâbhiwarddhate.

S. $2643 b$ en $2644 a: \ldots$ wairam waireṇa Keçawa wyupaçâmyati,.....' 'gnir yathâ....

J. ikang wera ngaranya kadi paḍema tikâ dening wera, kadyangga ning apuy deni hoti miñak, mangkin wṛddhi pinakaswabhâwa nikâ: "dat vijandschap zou uitgedoofd worden door vijandschap is evenalsof vuur zou gedoofd worden door offerolie, hun aard is, dat het hoe langer hoe meer toeneemt.»

J. fol. 33, r. 2: Nirddheheyam Kurûn sarwwân $=\mathrm{S}$. 2668b: nirdaheyam....

J. irika ta nghulun guměsenga ya tar maweha çeșa: "hen zal ik verbranden zonder iemand over te laten». Daarna volgt:

J. fol. 33, r. 3: Na jâtu gamanan tatra bhawet Pârtha nararthakam,

arthaprâptị kadâcit syat antato wa hy awâcyate.

S. $2669: \ldots$ nirarthakaṁ,.... syâd.... wâ' py awâcyatâ.

J. tan nirarthaka ta pwa laku ni nghulun, sâjñâ haji, kunang pih bhedanya, kasiddhan ikâ sasinâdhya kawit gati nikâ, ndân pilih pati ta pwâwasânanya: "mijn gang is niet doelloos, vorst, doch er is nog een onderscheid, soms slaagt alles wat ik mij voorneem, maar misschien is de dood het einde ervan.»

J. fol. 33 , r. 4 : Swasti prâptihi gamyatam் $=$ S. $2670 a$ : (yat tubhyam rocate Kṛ̣na) swasti prâpnuhi Kaurawân.

J. ndah suka yâtra ta rahadyan sanghulun: "moogt gij een gelukkige reis hebben.»

J. fol. a, 34, r. 3: Girer iwa laghutwan tat çîtatwam iwa pâwakaḥ $=$ S. $2741 a \ldots$ pâwake.

J. kadi rûpâ ning wungkal dady asahanya, kadi lwir ning apuy yan matîsa: "evenals een rots, die geslepen zou worden, evenals vuur dat koud zou zijn.

De O. Jav. vertaling is onnauwkeurig, want in het Skr. staat: evenals lichtheid van een berg.

J. fol. a, 34 , r. 4: Tasmat prasâmam iccasi $=\mathrm{S}, 2755 b$ ultimo: tasmât praçamam icchasi.

J. apa hetu rakryan kahanañ cittopaçama: "wat is de reden, 
dat uw hart bevredigd is? In het Skr. staat: daarom wenscht gij bevrediging.

J. fol. a, 35, r. 3: Trahamam puṇḍarikakṣa $=$ S. 28996: trâyaswa Puṇ ḍarîkâkṣa.

J. tatan hana çaraṇâçrayaa ni nghulun waneh, bheda sangke parameçwara; "ik heb geen andere hulp of bescherming dan u, vorst.» In het Skr. staat eenvoudig: red, Lotusoogige.

J. fol. a, 38, r. 2: Na mâm Mâdhawa wedawya nârthanâço weri tatha,

tathâ çekaya dawate yathâ putre winâ bhâwam.

S. $3198: .$. waidhawyam .... na wairatâ,.... çokâya dahati... putrair... bhawah.

J. ta kalarangku n kari bapanta sang lumah ing Çataçrnggga, tak âçaku $\mathrm{k}$ daridra kasyasih, tan prihatin ing musuh, kunang ikâ prasiddhâgawe çînṇ̣̣a ning hati, papasahku lâwan sang Pâṇdawa, mwang dewî Dropadî juga: «ik treur niet over uw vader, die begraven is op den Çataçṛngga, ik vrees geen armoede of ellende, ik ben niet bezorgd over vijanden, doch hetgeen mij werkelijk hartzeer veroorzaakt, dat is, dat ik gescheiden ben van de Pâṇ̣awa's en ook van Draupadî.

J. fol. 38, r. 1: Twan dharmma twan tapo mahat $=\mathrm{S}$. 3233b: dharmmas twam satyam....

J. kita marika dharmma, kita marika tapa: "gij zijt deugdzaam, gij zijt een asceet.»

J. fol. 38 , r. 2: Twan trata twa mahâbrahma $=\mathrm{S} .3234 a$ : twam bhrâtâ twam mahat.

J. kita rakwa rakṣa sih satata, kita nitya pinakâtmamantra: "gij zijt immers altijd een beschermer, gij strekt voortdurend tot eigen tooverspreuk.

J. fol. 38 , r. 4: Kṛtârthâh bhujatẹ̣ dûtâh pûjâ g̣̣hṇanti cewa naḥ,

kṛtârtham ma sahâmatyaḥ twamiwiṣyati Bhârata.

S. 3255: Kṛtârthâ bhuñjate.... pûjầ .... caiwa ha,... mâm sahâmâtỹam samarccișyasi...

J. Sâjñâ haji, mahârâja Duryyodhana, ikang dûta tělas siddha prayojana ktikâ, mukti sarwwabhoga, yânanggap sopakâra ning kadi rahadyan sanghulun prabhu, kalinganya, měne nghulun pinaripûjâ de haji, yan huwus mangguh ikang iṣțasâdhỵa, apa 
tan iningûpakâra kahyun i nghulun an para: "met uw verlof, koning Duryyodhana, de boden die zijn geslaagd in hun doel en alle genietingen genieten, die ontvangen alle weldaden van lieden zooals gij, vorst, d. w. z. nu worden wij geprezen door den vorst, omdat wij onzen wensch en ons doel bereikt hebben, waarom is ons verlangen niet ingewilligd, toen wij kwamen?

J. fol. a, 39, r. 3: Guṇawantañ ca yo dweșți tam âhuḥ puruṣadhanam $=$ S. $3265 b \ldots$ puruṣâdhamam.

J. ikang wwang mailik ring mamangguh guṇa rakwa, yekâ sinanggah wwang adhama: "iemand, die deugdzame lieden haat, die wordt een laag man genoemd.»

J. fol. a, 39, r. 4: Sarwwam etat abhoktawyam ana dûșta bhiṣahitam $=\mathrm{S}$. 3268a $: \ldots$. etan na bhoktawyam annam duṣțâbhisamihitaḿ, J. tan pinangan rakwa sěkul ning mangkana, apan karaměsan gělah rakwa ngaran ing bhojana mangkana: "de rijst van dergelijke lieden moet men niet eten, want dergelijk voedsel heet door onreinheid bezoedeld.»

In de O.Jav. vertaling staat eigenlijk de Indicatief-vorm pinangan. Hier is het êchter de vertaling van Skr. bhoktawyam. Het is eigenaardig, dat het Skr. woord anna (spijs) hier door sěkul (rijst) wordt vertaald, waaruit blijkt, dat reeds in de $11^{\mathrm{e}}$ eeuw rijst het hoofdvoedsel was op Java, evenals tegenwoordig.

J. fol. 39 , r. 3: Ekaḥ Karṇṇa parẫñ coyaḥ sa mârthạ̣ iti niçcitah=S. 3287a:... Karṇṇah... jetum samartha.... niçcitami, J. yayâ kětâ wěnanga sang Karṇṇangalahakna ng musuh akweh, yadyapi tunggatunggala, mangkanâbhiprâya niçcaya ri hati: "en zoo toch zal Karṇna in staat zijn, vele vijanden te overwinnen, al is hij ook geheel alleen, zoo is het vaste besluit in zijn hart. .

J. fol. 39 , r. 4: wadhireștiwa gâyanah $=$ S. $3290 b$ : badhireșw iwa...., J. kadyangga ning kidung an tan kahiḍĕp dening tuli: "evenals een gedicht (gezang), dat niet wordt gehoord door doove lieden.» Onmiddellijk daarop volgt:

Anupâsita dhṛdoyam sreyo mohaçca wetasi, wayodapâdamașarcca na te wakyang grahîsyati.

S. 3295: Anupâsitawṛ̂ddhatwât çriyo darppâc ca mohitah ,

wayodarppâd amarṣ̂a ca .... çreyo ....

J. iking Kurupati tapwan sewaka ri wwang atuha, moha ta 
ya dening keçwaryyan, mawerö dening wayah, sarwy agöng krodha, ring kapana tikângrèngwakna sojar parameçwara: Deze Duryyodhana hier heeft geen eerbied voor zijn vader, hij is verblind door de heerschappij, opgewonden door zijn jeugd, en tevens zeer toornig, hoe zou hij luisteren naar de woorden van den vorst?:

Uit deze vertaling blijkt, dat in den Skr.-tekst, dien de O.-J. vertaler gebruikte, inderdaad waky am stond, terwijl de Calcuttaeditie creyo heeft.

J. fol. a, 40, r. 2: Yâ me pritîh Pạnḍaweṣu bhùyat sâ twayi Mâdhawa,

prehna ca bâhumanañca suçrușaç ca wrawișyaham.

S. $3306: \ldots$ bhûyah.... premnâ ca bahumânâc ca sauhṛdàc ca brawimy aham.

J. sih ni nghulun ri sang Pândawa kèta pinakâsih ni nghulun, dening asih lâwan atwangta hetu nikân wěnang pinakanghulun makojar ikâ, mwang kabhaktin i nghulun ri rahadyan sanghulun: "mijne genegenheid voor de Pâṇ ḍaw's is mijne genegenheid (voor u), uit genegenheid en eerbied voor $\mathrm{u}$, dat is de reden, dat ik gerechtigd ben, dit te zeggen, en uit toewijding aan u.

J. fol. a, 40, r. 4: Parỵyastâm pṛthiwîm sarwwâm sâçwâm sarathakuñjarâm,

yo mocaret mṛtyupâçât prâpnuyat mokṣami uktamamin.

S. 3312:... mocayet... prâpnuyâd dharmmam uttamam.

J. iking pṛthiwîmaṇ̣̣ala ya magĕrah saha lâwan kuda liman mwang ratha, hana pwa wĕnang-wěnang luputakna sakeng mṛtyupâça, byakta pamangguh ikâ kamokṣapada: "deze aardbol is ziek met zijne paarden, olifanten en wagens; als er iemand in staat was, die te verlossen van den strik des doods, zou hij zeker de plaats der verlossing verkrijgen.»

In de O.J. vertaling leze men: byakta n pamangguh. Blijkbaar heeft in den Skr. tekst, dien de O.Jav. vertaler voor zich had, mokṣam gestaan, terwijl de Calcutta-uitgave dharmmam heeft.

J. fol. a, 40, r. 4: Wyasane wamantyamanam yo mitran nâbhipadyate,

maddhyarthîya yawaçakti tam n ̣̣çamsa widur wudhâh.

S. 3317 :... kliçyamânam hi..... anunîya ya thâçakti tam n ṛçámsami... budhâh. 
J. hana ya wwang tan tulung mitranya sẹḍeng katěkan duḥka bhâra, hana ta kewala muḍasina, ikâ ta wwang mangkana, yaya pâwak ning kujana, rakwa ling sang paṇitita: "er is iemand, die zijn vriend niet helpt, terwijl hij door een zwaar ongeluk getroffen is, doch er kalm bij toekijkt, een dergelijk man is de belichaming van een slecht man, zoo zeggen de wijzen.

In de O.Jav, vertaling leze men udâsîna in plaats van mudasina.

J. fol. 41, r. 4: Trâhi râjann ima lokam̉ na naçyeỵur imâh prajâh,

twayi prakṛtim âpanne çeșa syat kurutkurutma.

S. 3416:.... imaṁ...., .... çeșaḥ syât Kurunandana.

J. rakṣan ta pwa iki rât de haji, yatanyan tan çînṇ̣a parawaça, solah ing prabhu ri lagi rakwa solaha rahadyan sanghulun, marapwan wěnang tantw anuwuhakna wangça wěka rahadyan sanghulun: "Moge toch de aarde door u, vorst, beschermd worden, opdat zij niet verdelgd worde of in de macht van anderen kome; moge het gedrag der vorsten in vroeger tijd uw gedrag zijn, opdat uw geslacht in staat zij, uw stam voort te zetten.

J. fol. 42, r. 1: Dharmmato sampradhâryyaiwa yadi satyam wratity aham,

pramuñcohan mṛtyupâçât kṣatriyân kṣatriyansabhâ.

S. 3436: Dharmmârthau.... brawîmy aham̉, pramuñcemân.... puruṣarșabha.

J. Sâjñâ haji, mahârâja Dhṛtarâșțra, kami wruh mangingötingöt bheda ning dharmma lawan artha, tatan kadi sanghulun tan satya wuwus, kita marah, sâjñâ haji, haywa kari kita tan luputakěn ikeng kṣatriya kabeh saka ring mịtyupâça, apan kita wiçeșa ning kṣatriya: "met uw verlof, koning Dhṛtarâșțra, wij weten het verschil tusschen deugd en voordeel goed te onderscheiden, lieden zooals wij spreken geen onwaarheid. Welaan, vorst, laat niet na, al deze kṣatriya's te verlossen uit den strik des doods, want gij zijt de voortreffelijkste der kșatriya's.»

Uit het slot der O.J. vertaling blijkt, dat in den door den O.J. vertaler gebruikten Skr. tekst stond: kṣatriyarșabha, terwijl de Calcutta-editie heeft: puruṣarșabha.

J. fol. 42, r. 3: Râjâ Dambhodbhâwa namaḥ sarwwabhomah purâ' bhawet,

akilam bubhuje sarwwâm pṛthiwîm inạ̣ çrutam. 
S. $3452: \ldots$ Dambhodbhawo nâma sârwwabhaumaḥ.... 'bhawat,

akhilâm.... iti nạ̣ çrutam.

J. hana rakwa sang Dambhodbhawa ngaranya, ratu cakrawartti ring âsîtkâla, kawaçânût ikang pṛthiwìmaṇḍạ̣a de nikâ sang ratu, mangkana ng wṛtta pangrěngö mami: "er was, zegt men, een zekere Dambhodbhawa, een machtig vorst in ouden tijd, aan wien de aardbodem onderworpen was, zoo luidt het bericht, dat wij gehoord hebben.»

J. fol. 42 , r. 4 : Asti kaçcit wiçișța nam madwidho wâ bhawet yudhi.

S. $3454 a: \ldots$ kaçcid wiçișțo wâ....

J. hana kari lěwiha sangka ri nghulun, athawâ yan paḍa kunang, yâwat ring raṇamanggala: "Zou er soms iemand machtiger zijn dan ik, of mij evenaren op het slagveld? 》

J. fol. a, 43, r. 3: Naro Nârâyaṇaç caiwa tapasâm iti nạ çrutam,

trailokyâsmin hy api wibho ko na jânâti tatwata h

S. 3461 ..... tâpasâw...., âyâta u mânuṣe loke tâbhyâm yuddhyaswa pârthiwa.

J. hana rakwa sang hyang Nara Nârâyaṇa çakti manghanâkěn tapa rakwa, sira pangrěngö mami, tan hana ulya apagěh ring tribhuwana yâwat kaparamârthan ira, ya tikâ syanganta laga: "er zijn, zegt men, Nara en Nârâyaṇa, die krachtige ascese verricht hebben, naar wij vernemen, kan niemand in de drie werelden hen overtreffen in voortreffelijkheid, daag die uit tot den strijd!»

Het slot der O.J. vertaling is hier.meer in overeenstemming met de lezing der Calcutta-uitgave dan met de geheel afwijkende lezing van het Skr. vers in den tekst.

J. fol. a, 45, r. 1: Dewamanuṣaloka dwe manuṣanewa cakṣuṣ̂,

awagawe wacarako na ca me rocate wara.

S. 3517: Dewamânuṣalokau dwau mânuṣeṇaiwa...., awagâhyaiwa wicitau.... warah.

J. tělas kahasan ikang dewaloka mwang manuṣaloka de ni nghulun, sahângingöt-ingöt, sakaton dengku, nda tan hana juga karmma ny anakta, kapwa tolih lumihat, matangnyan tan Dl. 69. 
mantwa dewatâ, tan gandharwwa, tan siddharṣi, ngûniweh yan manuṣâ: "ik heb de godenwereld en de menschenwereld doorgezworven, en ik heb goed opgelet op alles wat ik zag, maar er is geen echtgenoot voor mijn kind onder allen, die ik gezien heb, daarom zij geen godheid mijn schoonzoon, geen gandharwa, siddharși of mensch.»

J. fol. a, 45, r. 2: Rûpato dṛçyate kaçcit wâgetu bhawitâ dhruwami.

S. 3520b:... kaçcin nâgeșu....

J. Sugya hana janma paripûrṇṇa ring nâgaloka, tontona ni nghulun ta ya: "misschien is er een volmaakt persoon in de slangenwereld, daar zal ik gaan kijken.»

J. fol. a, 45, r. 3: prawiweça mahîtalam $=$ S. $3521 b$, ult. = J. lumumpah ikâ sang Mâtali mare pâtâla: "Mâtali ging naar de hel.» In het Skr. staat: hij drong binnen in de aarde.

J. fol. a. 45, r. 3: Ahan te sarwwam akyasye darçayan wasudhâtalam,

swadṛștâ tatrawa kaçcit rocayitwâ ca ma ciram.

S. 3526:... âkhyâsye...., dṛșțwâ tatra waram̉ kañcid rocayișyâwa Mâtale.

J. Sang Mâtali! kumwâ deyanta měne harah: warahangkwa rikang sarwwawastu lâwan ikang Baruṇarâjya, katon mahâdbhuta wiçeșa denya, haywa ta jěnck, sugya tan kahantya dentângiṇdangi sarwwa katinghalan: "Mâtali! laten wij nu aldus doen: ik zal u inlichten omtrent alle zaken en het rijk van Baruṇa, zoodat gij de voornaamste wonderen ziet, wees niet ongeduldig, misschien wacht gij niet bij het zien van al die zaken.»

J. fol. 45, r. 4: Tasmat gaccati ma ciram $=$ S. $3546 b$ ult.: tasmâd gacchâwa mâ ciram.

J. nda haywa tika jĕnök sang Mâtali, nihan tontonanta waneh: "maar wees niet ongeduldig, Mâtali, hier ziet gij weer iets anders.»

In den Skr.-tekst staat eenvoudig: laten wij beiden daarom spoedig gaan.

J. fol. a, 46, r. 1: Atha mṛtam sureḥ pîtwâ nihitan iwataribhih,

tataḥ somyasya hâniç ca wṛddhiç caiwa pradṛçyate. 
S. 3550: Atrâmṛtam suraiḥ.... nihatâribhih, ataḥ somasya....

J. ngke kahanan ing amṛta, ikang ininum de ning watěk dewatâ, matangnya katon alwang atamběh ikang wulan: "hier is de plaats van den onsterfelijkheidsdrank, die gedronken is door alle goden, waardoor men het afnemen en wassen van de maan ziet. .

In de O.-Jav, vertaling is het woord nihatâribhih (na hunne vijanden gedood te hebben) overgeslagen.

J. fol. 46 , r. 1: Hiraṇyapuram ity etat kyâtam puracaram mâhat.

S. $3567 a: . .$. ity ewa khyâtam purawaram mahat.

j. Hiraṇyapura ngaran iki, kaḍatwan ing daitya dânawa: * Hiranyapura was de naam van een rijk der daitya's en dânawa's.s

J. fol. a, 47, r. 3: Kaḥ pitâ jananî wakya tatam asyema bhoginah.

S. 3636a: .... wâ'sya katamasyaiṣa ....

J. sangapa makânak iki, makawangça ya ngke ring nâgasamûha: "wie heeft dezen tot kind, tot wiens geslacht behoort hij hier in de slangenmenigte?"

J. fol. 47, r. 2: Asya kanyâ wararowah rûpenam sadṛçî bhuwi,

kulâçîlâg uṇopetah Guṇakeçîti wiçrutâ.

S. $3647 \ldots$ warârohâ rûpeṇâsadṛçî..., satyaçîlaguṇopetâ...

J. hanânak rasiki strî sĕḍ̆ng rarâ, tan paḍa pwa ring rûpa yan ring loka, sujanma suçîla, wihikan ring guna ning strî : «ik heb eene dochter, nog maagd, onvergelijkelijk in voorkomen hier op aarde, van edele geboorte en een edel karakter, bekend met de deugden der vrouwen.»

De O. J. vertaler heeft de laatste woorden van het Skr. vers (Guṇakeçîti wiçrutâ) niet vertaald.

J. fol. a, 48, r. 2: Asya dehakaras tanah mama putro mahâmuneh ,

bhaktito Wainateyena duhkârthah smewa te wayam.

S. $3657 b$ en $3658 a$ :.... tâta.... mahâdyute, bhakṣito.... duḥkhârttâs tena wai.... 
J. sâjñâ maharṣi! Ikânak ni nghulun pakabapa nikâ si Muka, yatikâ tělas winwatakěn i sang Garuḍa, makahetu göng ning kabhaktin, yatikâ matangnyan tapwan asamun sanghulun, de nikâhilang ikâ sang lunghâ, kunang angde lara těměn: "met uw verlof, groote ziener! Mijn kind, waarvan ik de vader ben, Muka, die is aangeboden aan Garuḍa, wegens zijne groote aanhankelijkheid, dat is de reden, dat het mij niet verborgen is, dat hij verdwenen is, doch dit veroorzaakt mij groote smart.»

In het Skr. vers staat, dat Sumukha door Garuḍa verslonden is. De vertaler denkt bij bhakșito aan bhakti, dat er niets mede te maken heeft.

J. fol. 48, r. 4: Âhâro wihito catra kimartha wâryyate twayah $=$ S. $3677 b \ldots$ dhâtrâ kimartham ... twayâ.

J. apa kariki tan paweh bhațâra Jagadnâtha karikang nâga, apa ta dumehta wâdhaka ri swabhâwanta: "heeft god Jagadnâtha mij de slangen niet toegestaan? Wat is dan de reden, dat gij u verzet tegen uw eigen wezen?»

J. fol. a, 49 , r. 2: Mama Dakṣasya ca suta jananî Kâçyapa pita,

aham apy utsahe lokân samâstan wợhum âjasâ.

S. 3683: Mamâpi Dakṣasya sutâ.... Kaçya pạ̣ pitâ,.... samantâd.... a ñjasâ.

J. anak bhagawân Dakṣa sang ibungku dewî Winatâ, bhagawân Kaçyapa ngaran sang bapangku, yaya wěnang aku kumawaçâkna jagat, makanimitta göng ni kaçaktingku: "mijne moeder is Winatâ, de dochter van Dakṣa; Kaçyapa is de naam van mijn vader; dat ik in staat ben, de wereld te beheerschen, dat is toe te schrijven aan mijn groote macht.»

J. fol. a, 49, r. 3: Garutman manyase 'tmânam balawantam sudurbbalah,

alam asmat syawaksyan te stotum âtmânam aṇaja.

S. $3692: \ldots$ sudurbbala, .... samakșan ....

J. ai sang Garuḍa, pijerr kumawruhi çaktinya ngaran i mangko, tan wruh yan huwus durbbala, haywa ta mastuti çarintenya ri harěp ning kadi kami: "o Garuḍa, aan niets anders denken dan aan zijn macht, zoo heet uwe handelwijze, gij weet niet, dat gij zwak zijt. Prijs u zelf niet in tegenwoordigheid van iemand zooals wij!» 
J. fol. 49, r. 1: Nipapâta sanârato wihwaho nașțawetanaḥ $=$ S. 3695b:.... sabhârârtto wikalo nașțacetanah.

J. tibâ ta sang Garuḍa, mûrcitâlupa tanpacetana: "Garuḍa viel, bezwijmde, viel in onmacht en werd bewusteloos». Onmiddellijk daarop volgt:

yawaddhi bhâra kṛtsnâyâh pṛthiwyâh sarwwetas saha,

ekasyạ̣ dehasakayah tawât bhâram amanyata.

S. 3696: Yâwân hi bhârạ̣.... parwwataị̣...., ekasyâ dehaçâkhâyâs tâwad....

J. apayapan bwat ning pṛthiwîmaṇụala saha mwang wukirnya pinakabwat ning bâhu bhațâra hyang Wiṣnu hị̣̌p sang Garuda: "want zooals het gewicht van den aardbol met zijne bergen, zoo zwaar was de arm van god Wiṣṇu, naaar de meening van Garuda.»

J. fol. 49, r. 3: Bhagawan lokasârasya sadṛçena bapuṣmatâ,

bhujena swairamuktena nipișțo'smi mahîtale $=$ S. 3700: ${ }^{\circ}$ mahâbala.

J. sâjñâ bhațâra! Mahâbhâra dahat bwat ni bâhu rahadyan sanghulun, paḍa lâwan pṛthiwîmaṇ̣ala, lîlâ ta pinakanghulun tan andělakna ri pinakanghulun, tathâpi kapěñět kapaliṇ̦̣̆s ring lemah nghulun denya: "met uw verlof, heer! zeer zwaar is het gewicht van uw arm, even zwaar als dat van den aardbol; langzamerhand kan ik het niet meer uithouden, doch ik word er door verpletterd en neergedrukt op den grond.»

Uit de O.J. vertaling blijkt, dat in den Skr. tekst, dien de O.Jav. vertaler gebruikte, werkelijk mahîtale stond, terwijl de Calcutta-editie mahâbala heeft.

J. a, 50, r. 3: Uttam̉ bhagawânta wakyam uktam̉ Bhîṣmeṇa yat kṣamaḿ,

uktam bahuwidhañ caiwa Nâradenâpi tat çṛnu.

S. 3717: uktam் bhagawatâ wâkhyam....

J. tanayan mami sang Duryyodhana! Kennoh tojar mâhârâja Kṛ̣ṇa , tan salah tangguh bhagawân Bhîṣma, yukti warawarah sang rṣi Nârada, yatikâ sẹ̣̣eng hị̣̌pěnta: "mijn zoon, Duryodhana! Juist zijn de woorden van koning Kṛṣna, niet onwaar de vermaning van heer Bhîṣma, passend de vele aansporingen van den ziener Nârada, die moet gij ter harte nemen!» 
J. fol. 50, r. 1: Wiçwamitra tapasyantam Dharmmo j jñâsayâ purâ,

abhyataccat swayam bhûtwâ Waçișța bhagawan ṛwi.

S. 3721: Wiçwâmitrami..., abhyâgacchat.... Waçișțho bhagawân ṛ̣i.

J. ngûnî ring âsîtkâla bhagawân Wiçwâmitra manghanâkěn tapa. Pira ta pwa lawas nirâtapa, pinaran ta sira de bhațâra Dharmma, pinarîkṣâ göng ni kabhaktin ira, ndân bhațâra Dharmma makarûpa bhagawân Waçișțha: "vroeger in ouden tijd verrichtte Wiçwâmitra ascese. Nadat hij nu geruimen tijd ascese had verricht, kreeg hij bezoek van god Dharmma, die den graad van zijne toewijding wilde beproeven en god Dharmma nam de gedaante aan van Waçișțha.»

J. fol. 50 , r. 3: Bhuktam me tiṣța tawâktum=S. 3725a: .... tiṣțha tâwat twam.

J. sâmpun warĕg akw amangan, pangher juga kamung ri pangadeganyu: «ik ben verzadigd van het eten, blijf gij toch staan op uw plaats!»

J. fol. a, 51 , r. 2 , Kșatrabhâwâd apagato brâhmaṇatwam upâgataḥ,

Dharmmasya wacanât prîto ninnastasas kadâbhawat $=$ S. $3731 \ldots .{ }^{\circ}$ Wiçwâmitras tathâ'bhawat.

J. irikâ tambe bhagawân Wiçwâmitra mari makajâti kṣatriya, çuddha brâhmaṇa çarîra nira de ning anugraha bhațâra Dharmma, suka tușțâmběk nira tuměmu ng saprayojana: "van toen af hield Wiçwâmitra op, de inborst van een kṣatriya te hebben, en werd hij rein van lichaam als een Brahmaan door de gunst van god Dharmma; zijn gemoed was tevreden en voldaan, daar hij al wat hij wenschte verkregen had.»

J. fol. a, 51, r. 3: Dakṣiṇ̂ạ kâh pragaccami bhâwetu çubhakarmmane $=\mathrm{S}$. $3734 b: \ldots$ prayaccchâmi bhawate gurukarmmaṇi.

J. sâjñâ mahâmuni! Aparan ikâ pangguruyâga paweha rânak maharși : "met uw verlof, groote wijze! Wat zal ik geven als offer aan mijn leeraar?

J. fol. 51, r. 2: Moham prạ̣ami wimokṣyâmi kṛtwâ yatnam anuttamam,

artita na mayâ kaçcit kṛttapûrwwe diwakâçam. 
S. $3753 b$ en $3754 a$ : so'ham prânân ...., arthanâ .... kâcit kṛtapûrwwâ diwaukasâm.

J. Aku kěta yakșatyaknâwaku de ning prihati, ta pwa ya pagawaya prih kotsâhan rumuhun, tapwa kami aminta warânugraha ri dewatâ: "ik zal mijn lichaam verlossen van smart, na mij eerst ingespannen te hebben, wij hebben nog geen gunstbewijs aan de goden gevraagd. $\gg$

Het woord yakșatyakna is corrupt. Het is de vertaling van Skr. wimokșyâmi (ik zal verlossen).

J. fol. 51, r. 4: Aḍ̂geșțo'smi dewena Gâlawa jñâtoy oççinâ,

çruti kamanumi yâmi dṛṣtâm paḍamato diçam.

S. 3761: Anuçișțo .... jñânayoninâ, brûhi kâman tu kâm .... drașțum prathamato ....

J. sojar sang r̦̣̦i Gâlawa, nghulun prasiddha inuddeça de bhațâra hyang Wiṣṇu, kumawruhana sang yogî sira kabeh. Aparan ta kahyunta, toh warahakěn, yan deça tapwan kabhyasan tuwi, nghulun wěnanga mara ngkâna: "Zooals de ziener Gâlawa zegt. Ik ben inderdaad aangewezen door god Wiṣṇu, om alle yogin's te leeren kennen. Wat is uw verlangen, deel het mede, al is het een onbewoond land, opdat ik in staat zij, daarheen te gaan.»

J. fol. a, 52, r. 1: Açca paçcad ahah sûryyo wisarjjayati bhâh swajâ,

paçciteteçcapaçcimah dig iyam dwijassattama.

S. 3802: Atra paçcâd .... gâh swayaṁ, paçcimetyabhiwikhyâtâ ....

J. iking deça panglępasan sang hyang Âdityateja, paçcât ri wěkasan yeka ring paçcimadeça: "dit land is de plaats van de loslating (verspreiding) van den Zonneglans, paçcât, ten slotte, in het oosten.

J. fol. a, 52 , r. 2: Tasmat uttâryate pâpât utpannâçramino yatah,

tasmat uttâraṇaḍanat uktirecy utyate kacit.

S. 3821: yasmâd ... yasmân niçreyaso'çnute, asmâd .... balâd uttarety ucyate dwija.

J. ikang hawan sang catur âçrama anětas ing kapapân, tasmâd uttâraṇa pwa hawan ing manětas, yapwa pinakaphala, 
tasmât nahan ta ngaran ikang deça ring uttara pwa, kumwâ kalinganya, sakaharěpta kamung ṛ̣i Gâlawa: "de weg, waarop de vier kasten de boosheid doorbreken (vermijden), heet u t tâ ra ṇa; dit nu is de weg van het doorbreken, als nu dit tot belooning strekt, daarom heet deze streek het Noorden (uttara), zoo is de bedoeling ervan, geheel volgens uw wensch, ziener Gâlawa.»

In de vertaling der voorafgaande verzen gaat de woordspeling, waardoor paçcima wordt afgeleid van paçcât en uttara van uttâryate geheel verloren.

J. fol. a, 52 , r. 4: Kramamânasya te rûmam dṛçyate pannagâçana,

bhâskarasyewa pûrwwâhṇe sahaçrangçoḥ wiwaswatah.

S. 3855 :... rûpam ...., .... sahasrâm çor....

J. kamung Garuḍa, ikâ lwir ning katon de ni nghulun, mangke ri lakunta, sâkṣât bhațârâditya ri sakatembesuk ta pwa rûpanta: "gij, Garuḍa, vertoont u voor $\mathrm{mij}$ in uw gang evenals de Zonnegod in den vroegen morgen, zoo is uw voorkomen.»

J. fol. 52 , r. 2 : Na çṛnomi na paçyâmi nâtmano wedmi kâraṇam $=\mathrm{S}$. $3860 b$.

J. kapatuli tan wěnang mulat, wulangun tar wĕnang $i$ deya: "verdoofd, niet in staat om te zien, verbijsterd, niet wetende wat te doen.» Onmiddelijk daarop volgt:

çane sâdhu bhawân yâtu=S. 3861 $a$ : çanaih sa tu....

J. kasihana kamung Garuḍa, pahalontaku lakunta: "wees zoo goed, Garuḍa, langzamer te gaan.»

In de O. J. vertaling leze men in plaats van pahalontaku: pahalonta. Dan volgt:

Tama drawa tu paçyâmi çarîran te na lakṣaye,

maṇi wâ jâtya paçyâmi hy awidehaç cam aṇ ḍaja.

S. 3862: Tama ewa....,... jâtyau .... cakṣuṣ̂i te 'ham...

J. pětěng juga panon i nghulun, pisaningu katona çarìranta, tuhun matanta kalih juga ya katon lumöng, kadi maṇik jâtinya: "mijn gezicht is verduisterd, hoe zou ik uw lichaam zou kunnen zien, slechts uwe beide oogen zie ik schitteren als juweelen.»

J. fol. 52 , r. 4 : Na câpi kṛtrimaḥ kâlạ̣ kâlo hi parameçwaram $=\mathrm{S} .3870 b ., \ldots$ parameçwarah.

J. winalingnya $\tan$ wěnang ginawe karikang kâla ngaranya yar těkanya, apan bhațâreçwara wastu kâla ngaranya: "naar 
zijne meening kan niet gemaakt worden, dat de tijd komt, want god Îçwara heet inderdaad Kâla.»

J. fol. 53, r. 1: Na bhedawyam Suparṇo 'si Suparṇe tyaja sâmbhrasi.

S. $3884 b: \ldots$ bhetawyam .... Suparṇa .... sambhramami.

J. haywa kitâtakut sang Garuḍa, ta huwusanârohara: "wees niet bevreesd, Garuḍa, houd op met ontsteld te zijn!»

J. fol. 53, r. 2: Âcâraḥ phalate dharmma âcârah phalate dhanam,

âcârât çriyam âpnoti âcâro hanty alakṣaṇam.

S. $3887: \ldots$, dharmmam....

J. winalingnyu tan âcâra mârgga ning dharmma, hetu ning mâs kapangguh, âcâra pwa ikang halěp tuwi, âcâra ta humanaknikâ, ikang kadurllakṣaṇan hilang ikâ de ning âcâra: "is naar uwe meening niet een goed gedrag de weg tot deugd, de oorzaak, dat goud verkregen wordt? Zelfs schoonheid verwerft men door een goed gedrag, slechte voorteekens verdwijnen door een goed gedrag.»

De woordverbinding humanaknikâ in de O. J. vertaling is onduidelijk. Het is de vertaling van Skr. âpnoti. Waarschijnlijk moet men lezen: humanâkěn ikâ, waaarin humanâkěn beteekent: doet zijn, doet ontstaan.

J. fol, a, 54, r. 3: Yayâtir Nâhuṣo nâma sa dâsỵati mayâ ukto,

râjarṣih satyawikramaḥ bhâwitor witwatah swayam.

S. 3903: Yayâtir nâma râjarșir Nâhuṣaḥ satyawikramaḥ, sa dâsyati mayâ cokto bhawatâ cârthitah swayam.

J. hana sira râjarși, anak mahârâja Nahuṣa, mahârâja Yayâti ngaran ira, tuwi mahâçakti, niyata sirâwehana talangkup de ni nghulun: *er is een groote ziener, een zoon van koning Nahuṣa, genaamd Koning Yayâti, inderdaad zeer machtig, hij zal zeker geven, wat ik verzocht heb.»

De vertaling van talangkup is onzeker. Ook is de O.-J. vertaling onvolledig, vermoedelijk door de corrupte overlevering van het Skr.-vers.

J. fol. 56, r. 3: Jâto dânapatị patrah tatha çurạ tathah parah.

dharmmasatyarathasaç ca yajwâ wâpi tatạ̣ paraḥ. 
S. 4023: .... putras twayâ çûras tathâ'paraḥ, satyadharmarataç cânyo yajwâ câpi tathâ parạ̣.

J. tambentânak uttama ḍatěng puṇyâkweh pinakaswabhâwanya, tumût ta mahâçûra madhana, kapintiganya satwika ri gawe dharmma, wěkasnya gawe yajña gělěm amûjâ: "vroeger hebt gij een voortreffelijken zoon gekregen, begaafd met vele deugden, toen volgde een rijke held, ten derde iemand, die trouw zijne plichten vervulde, ten slotte iemand, die offers bracht en gaarne bad.»

J. fol. 57, r. 2: Awamene narân sarwwân dewaṛṣigạ̣an tatha,

Yayati mụ̣̂hawijñâno bhiṣmâyạ̣ yaçcacetanạ̣.

S. 4041: .... dewân ṛșigạ̣âms tathâ, Yayâtir .... wismayâwiṣțacetanaḥ.

J. amogha ta sirânghangkâra, awamâna ring dewatâ mwang ring r̦̣̦i, ngûniweh ring manuṣa, sinaput ring kamuḍan, niçcaya n pamanggih mahâwibhâwa: "doch hij werd zelfzuchtig en minachtte de goden en de zieners alsmede de menschen, gewikkeld in verbijstering, er op vertrouwende, dat hij een groote macht verkregen had.»

J. fol. 57 , r. 3. prâpakîmbur mahîtalam $=\mathrm{S} .4050 b$, ult.: pratipaçyan mahîtalam.

J. umeh tibâ ring bhûmitala: "bijna viel hij op den grond.»

J. fol. 57, r. 4: Atîwa madawatras twam na kañcit hawamanyase,

hanîna bhrașța swakaçca dahârswam patalatmajaḥ,

S. 4054:... madamattas... kiñ cin nâwamanyase, mânena

bhrașțạ swargas te nârhas twam pârthiwâtmaja.

J. kita arah mahârâja Yayâti! den hị̣̣ep bhrânta de ni wibhâwanta, yatikâ kâraṇanya awamâna ring sarwwajanma , ikâwamânanta ya tiku surudmu sakeng swargga: "o gij, koning Yayâti! Weet dat gij verbijsterd zijt door uw macht, dat is de reden, dat gij alle schepselen minacht, die minachting van $\mathrm{u}$ heeft u uit den hemel getrokken.»

J. fol. a, 58, r. 3: Ko nw ayami kasya wâ râjñạ̣ katham wâ swarggam agatạ, ,

karmmaṇâ kena siddho'yam̉ kwaca'nena tapaçcitam.

S. $4043 b$ en $4044 a$ :.... swa y a m âga ta h.,.... kwa wâ'nena.... 
J. syapa karikâ, syapa ratu, apa hetu nikân pareng swargga lewwih, aparan ta gawe rahayu huwus kasiddha denta, matangnyan milwa siddhadewatâ, ndi ku npagawaya tapa, mârgganyan tulusa bhukti haneng swargga: "wie is dit, wie is deze vorst, wat is de reden, dat hij den hoogen hemel bereikt heeft? Welke goede daad is door u verricht, dat gij een volmaakte god zijt geworden, welke ascese hebt gij bedreven, dat gij opgenomen zijt in den hemel?»

J. fol. a, 58, r. 4: Etasminn ewa kâle tu Naimiṣe pârthiwesabhâm,

caturo syaçyaḥtan mupạ̣ teșâm madhye papâta saḥ. S. $4056 b$ en $4057 a: \ldots$ pârthiwarṣabhân,.... 'paçyata nṛpâmis.... ha.

J. irikang kâla manon ta sira ratu patang siki, sẹḍ̆ng manghanâkěn yajña ring Nemișâraṇya, ri sanmuka nikâ sang ratu patang siki, ngkâ ta tampuhan irân tibâ: "toen zag hij vier vorsten, die juist een offer brachten in het Naimișawoud; voor de oogen van deze vier vorsten, daar was de plaats, waar hij viel.»

J. fol. 58, r. 2-3: Ko bhawân kasya wawanânduh deçasya nagarasya ca,

Na hi mânuṣarûpo'si ko pyatạ kângkṣyate twayâ?

Yayâtir asmi râjârṣi kṣiṇapûnỵah cyuto diwaḥ,

pateyam satsw iti dheyam bhawatsu patitah tathah.

S. 4063-4065: .... wâ bandhur .... wâ, .... wâ'rthah $\ldots . . . .$. râjarșih kṣinnapuṇyaç $\ldots . . . .$. dhyâyan .... winipâtitaḥ.

J. aparan kita, sangapa rinatwanta, deça ndi tiki sinangkanta, tan hana wwang mangkana lwirnya, mwang aparan tikâ prayojananta? Laki sang ratu mahâpuruṣa, nghulun râjarși, si Yayâti ngaran i nghulun, de ni hilang ning gaway ahayu matangnyan tibâ saka ring swargga, kunang tâpan aprârthana tibâ ning wwang mahâpuruṣa nghulun, nâhan matangnyan tampuh i sanmukanta: "Wie zijt gij, wie worden door u geregeerd, uit welke streek zijt gij afkomstig? Er is niemand, die er zoo uitziet, en wat is uw doel?» "Mannen, edele vorsten! Ik ben een koninklijke ziener, Yayâti is mijn naam, door het verdwijnen van mijne goede daden, daardoor ben ik uit den hemel gevallen, doch dat ik heb verzocht, te vallen onder edele 
menschen, dat is de reden, dat ik voor uwe oogen nedergestort ben.»

J. fol. 58 , r. 4: Nâ'han pratigrahadhano brâhmaṇaḥ kṣatriyo hy atam,

na ca me gracanah buddhạ̣ parapuṇyawinâçane.

S. 4067: Nâ'ham .... aham , .... prawạ̣â buddhị̣.....

J. nghulun laki tan brâhmaṇa, doyan puṇya kawwangan i nghulun, kșatriya juga kawwangan i nghulun, kapwan ta nghulun makâmběk matsara ri pagawe ning wwang len puṇya: «ik, mannen, ben geen brahmaan, die streeft naar verdiensten, doch ik ben een Kṣatriya van afkomst, en ik ben niet afgunstig op de verdienstelijke daden van anderen.»

In de O.-J. vertaling leze men tapwan in plaats van kapwan.

J. fol. a, 59 , r. 4 : Yesmât tena parah sarwwe apatyaphalabhâginah ,

tasmât iccâsa drohitran yathâ kwa wasudhâdhipa.

S. $4073 b$ en $4074 a$ : Yasmâd râjan narâh ...., tasmâd icchanti dauhitrân .... twam ....

J. yan hana wwang len sake rahadyan sanghulun ya mânaka satwikâgawaya dharmma kapanggiha juga phala ning mawěka de nikâ, yapwan mangkana, yan sâmbhara ning putu jalujalu sakeng anak strî paramârthanya, ikang putu sangke nghulun yâmaluyakna ring swarggaloka ri rahadyan sanghulun: "Als er een ander mensch is dan gij, die een deugdzaam kind krijgt, dat zijn plicht doet, zal degene, die hem tot kind heeft, het loon ervan genieten. Als dat zoo is, als er een kleinzoon van eene dochter geboren wordt, dat beteekent, als gij een kleinzoon krijgt, zal die u naar den hemel terugvoeren.»

J. fol. 59 , r. 2 : Pratyâbhikjñânamatro 'tha sarwwas te narapunggawah ,

Yayâti diwyasaswano diwyâbharaṇabhûșitaḥ.

S. 4078a en 4079: pratyabhijñâtamâtro 'tha sadbhis tair...... Yayâtir diwyasamisthâno (babhûwa wigatajwarah, diwyamâlyâmbaradharo)...,

J. enak ta tutur mahârâja Yayâti ri wëkasan, an hana sira kabeh, mwah ta sira dewatâ, masalin prakṛtibhûșaṇa: "ten slotte werden de gedachten van koning Yayâti gerust, omdat 
zij allen daar waren, hij werd weder een god en verwisselde zijne alledaagsche sieraden (voor goddelijke). »

J, fol. 59, r. 3: Dadâmy atha ca dâsyâmi tena samiyujyatâm bhawân,

yatalan dânaçîlasya samaçîlasya yat phalam.

S. 4082: tad apy...., yat phalạ̉ .... kṣamâçîlasya....

J. sěḍ̌ng awẹh dâna ngaran i nghulun mangke, hělěm sowah yayâ ta nghulun agawaya dâna punyaa, saphala ning madaměl dâna, mwang phala ning kopasaman, rahadyan sanghulun atah muktya ikâ: "ik geef juist geschenken, heet het van mij, later zal ik wederom gaven schenken en verdienstelijke daden verrichten, alle belooningen van hem, die gaven schenkt, en de belooningen van hem, die tot gemoedsrust is gekomen, die zult gij genieten. »

Uit de O. Jav. vertaling zou men opmaken, dat in den door den vertaler gebruikten Sanskṛt-tekst inderdaad dadâmy atha stond in plaats van tad apy atha, zooals de Calcutta-editie heeft.

J. fol. 59, r. 4: Wirașanda phalañcewa tena sangýujyate bhawân.

S. 4085a: Wîraçabdaphalañcaiwa .... samiyujyatâm....

J. tatan hanâmuktya phala ning sinanggah wîrapuruṣa, kaki sanghulun yatikâta mangguhakna: "er is niemand (anders), die de belooning zal genieten van hem, die een dapper man genoemd wordt, alleen mijn grootvader zal die verkrijgen.»

J. fol. a, 60 , r. 1: Yata prạ̣aç ca râjyañca râjan karmma sukadi ca,

jyatenane wa satyam tena satyena tam braja.

S. $4087 b$ en $4088 a$ : yathâ prânâmęc ca .... sukhâni ca, tyajeyam் na punạ.... kham wraja.

J. nya tang hurip lâwan kạ̣atwan, ngûniweh tikang karatun mwang wibhâwa, yayâ wěnang ni nghulun matinggalerikâ, kunang ikang satya pisaningun sira tinggalerikâ, matang yan ata kasatyan (i nghulun atah atinggalerikâ) mârgga rahadyan sanghulun umaluya ring swarggaloka: "het leven en de koninklijke waardigheid, alsmede het koninkrijk en de macht, die ben ik in staat op te geven, doch de waarheid, hoe zou ik die kunnen opgeven, want de waarheid is de weg, waardoor gij naar den hemel terugkeert. 
De woorden i nghulun atah atinggalerikâ in de O. Jav. vertaling zijn door mij tusschen haakjes gezet en niet vertaald, omdat zij eene herhaling van het vorige bevatten.

J. fol. 60 , r. 1: Eșa doṣo 'timanena purâ prâpto Yayâtica,

nirwandata tâtimatram mârggawena mahîpate.

S. 4116: .... doso 'bhimânena.... Yayâtinâ, nirbadhnatâ 'timâtrañca Gâlawena....

J. nihan tikang hala kapanggih de mahârâja Yayâti, doṣa nirâgöng awamâna, lâwan doṣa ning mamimilan mamangpang ring çabda ning wwang atuha, yekâ kapanggih de sang rṣi Gâlawa: "Zoo werd leed ondervonden door koning Yayâti. Zijn schuld was groote minachting en halsstarrigheid en onwilligheid jegens de woorden van oudere lieden, dit werd ondervonden door den ziener Gâlawa.»

J. fol. 60 , r. 3: Dharmmârthayuktâ lokesmin prawṛtti lakṣyate satâm,

asatâm wiparîtâ tu lakṣyate Bhâratarsabhâ

S. $4132: \ldots$ prawṛttir.... Bharatarșabha.

J. prawṛttîkâ sang sajjana dharmârtha juga wungkalanya, prasiddha katon ngke ring loka, ikang durjjana ngaranya, wiparîtanya juga kinâryya nikâ: "de handelwijze van brave lieden, daarvan is plicht en voordeel de hoofdoorzaak, zooals duidelijk blijkt in deze wereld, doch slechte lieden doen het omgekeerde daarvan.»

J. fol. a, 61 , r. 1: Satam matam atikramya yo 'satâm warttate make,

socante wyasane tasyah suhṛdo na wirad ica.

S. 4147: Satâm.... mate, çocante... tasya... cirâd iwa.

J. ikang wwang tan pamisinggih sang mahâpuruṣa, kědö sakta ring kaduṣkṛtan ing tan sajjana, yeka tan kinalarâkěn ing mitra yan katěkan duḥkabhâra: "iemand, die geen gehoor schenkt aan edele lieden, doch volhardt in zijne neiging tot slechte daden van booze lieden, om hem treuren zijne vrienden niet, wanneer hij getroffen wordt door een zwaar leed.»

J. fol. a, 61, r. 2: Kamârto lipsamânas tu dharmmam ewâditaç caret,

na hi dharmmâd amety artha tamo wâ 'pi katañcanam. 
S. 4158: Kâmârthau...,. ... a apaity arthaḥ kâmo... kadâcana.

J. yan artha lâwan kâma kahyunakna ikang wwang panggihakěnya, dharmma jugânung göngěnya rumuhun, dumeh ya mangkana, yayâ tan hilang ning dharmma, rumakět ikang kâmârtha, yâwat kadaměla ning dharmma: "als iemand voordeel en begeerte wenscht te verwerven, moet hij zich eerst op deugd toeleggen, want als hij zoo doet, dan zal de deugd niet verdwijnen, en begeerte en voordeel blijven verbonden, zoolang de deugd betracht wordt.»

J. fol. 61 , r. 2: Prasamîkșya bhâgawane waktum ahâti Keçawah,

mam ewam hi wiçeșeṇa wibhâṣya parigarppase.

S. 4234:... bhawân etad.... arhati Keçawa, mâm ewa.... parigarhase.

J. mahârâja Kṛṣna! Kayogyan ing kadi kita kěta ya, âlocita pûrwwaka juga ya, kaměnâ ning yuktyâwarawaraha, yapwan haywa parikědö humaleng kadi sanghulun wawang: "koning Kṛṣna! Het past iemand zooals gij, eerst na te denken, opdat gij naar behooren vermaant, als gij er niet op staat, iemand als ik spoedig slecht te behandelen.»

J. fol. 61, r. 4: Swadharmmam anutișțanto yadi Mâdhawa samyuge,

çâstreṇa nidḥanam kâle prâpyâmaḥ swarggam ewa tat.

S. $4247: .$. .. anupaçyanto...., astreṇa .... prâpsyâmaḥ....

J. mahârâja Kṛṣna! swadharmma ning kṣatriya juga gěgön sanghulun, yapwan kapanggiha ng pati ri tîkșṇa ning astra těngah ning palagan, swargga marikâ: «koning Kṛṣna! alle plichten van een kṣatriya zal ik betrachten; wanneer mij dan de dood treft door de scherpte der schichten midden op het slagveld, dan zal de hemel (mijne belooning zijn).»

J. fol. a, 62 , r. 1: Lapsyase witaçayanam kâlam ema walapsyasi,

sthiro bhawa sahamârtyo wimârddho bhîwatạ dhruwa m.

S. 4260: .... wîraçayanam kâmam etad awâpsyasi,.... sahâmâtyo wimardo bhawitâ mahân.

J. tuhu kapanggiha ng kapějahan ing kawîran těkapnya, 
kintu mangguha ng sukenak âmběk kamu, taha, tulusakěn tângěn-angěnyu sahabala, těka ring upadrawosön ri kamu: «inderdaad zal u de heldendood ten deel vallen door hem, maar gij zult gelukkig en bevredigd zijn. Kom! Wees standvastig met uw leger, het ongeluk zal u spoedig bereiken.»

J. fol. 62, r. 1: Kasam ekan parisâdhya kulartha sarwwayâdawâh,

sambhaya sukamedan te Bhâratan wakâwṛ̣nayah.

S. 4298: Kaḿsam ekam parityajya kulârthe ...., sambhûya sukhamedhan .... Bhâratândhakaw ṛṣnayaḥ.

J. Nâhan tika sang durâtmaka kewalya siki n (pakam) pinakâmběk kadușțan, tininggalakěn ya de sang Yadukula, tṛ̣ṇa ring wwang akweh tar ahat ring makẹdik, mapupul pwa sira kumabehîkang Kangsa, dadi kabhukti ng inak âmběk de nira: "Zoo werd de booswicht, die alleen aan slechte daden dacht, verlaten door het Yadu-geslacht, de groote menigte genegen, zonder eerbied voor de geringen, zij vereenigden zich en overvielen met hun allen Kangsa, waardoor hun gemoed bevredigd werd.»

Het woord pakam in de O.J. vertaling heeft geen zin en moet waarschijnlijk vervallen.

J. fol. a, 63 , r. 1: Waçyawahendriyâ râjam agniyat dîrgghyâm antarami ,

wijitâtmâ tu mâdhawî sa râjyam abhîjayate.

S. 4332: na hy awaçyendriyo râjyam açnîyâd dîrgham ....,.... ca medhâwî .... abhipâlayet.

J. apan ikâ wwang wihang, kědö tumûtakěn sângěn-angěnya, tan adawa ikâmanggih wibhâwa, kunang ikang wwang yạn wěnang humerrět manahnya kěta ring loka, tututnyan kiněnan tangguh, sira ta ikâpagěh de nira kumawaçâkěn kaḍatwan: "want een weerspannig mensch, die aanhoudend al zijne begeerten volgt, die geniet niet lang voorspoed, doch iemand, die in staat is, zijn geest te bedwingen hier in de wereld, en gehoor geeft, als hij vermaand wordt, die verovert vast een koningrijk.»

J. fol. a, 63, r. 2: Warddhate'gnir iwendhaneh $=\mathrm{S}$. $4335 b$ ult. : .... iwendhanaih.

J. kadyangga ning apuy tinahěnan: "evenals vuur bedwongen wordt. » 
Deze O.-J. vertaling is geheel verkeerd, want in den Skr.-tekst staat: "evenals vuur aangewakkerd wordt door brandhout.» Dit is dus juist het tegenovergestelde.

J. fol. a, 63, r. 3: Na yuddhe wâkra talyaṇami na dharmmâtho kutah sukam,

na warpi wijayo nitwam mà yuddhe wetâ akṛtah.

S. 4349: .... tâta kalyânạm .... dharmmârthau .... sukham, .... câpi .... nityami .... ceta âdhithâh.

J. lâwan ta weh bapa, yan papranga kita lâwan sang Pânḍawa, hana kari sukanta, ndyâng dharmmârtha tikâ puhara denta, kapana ng bhoga kabhuktya, ikang jaya parâjaya ngaranya, alib iwěh ikâ linakṣaṇan, matangnyan haywâhyun ing samara: "en verder, vader, als gij strijdt met de Pâṇ̣awa's, want dit is immers uw verlangen, hoe zou dit voor u deugd en voordeel ten gevolge kunnen hebben, hoe zoudt gij die genieten? Hetgeen overwinning en nederlaag heet, dat is zeer moeielijk na te gaan, streef daarom niet naar strijd!»

J. fol. 63, r. 2: Âsâdya na bhawiṣyanti patanggâ iwa pâwakam̉,

ayam icchan hatan sarwwân yatamano Janârddanah.

S. $4384: .$. . hi tân .... yuudhyamânân ....

J. kapana tan wĕnangomatyana sira, byakta kadi tâmpuh ing larularu ring pañjut himpĕr nira kabeh, mahârâja Kṛṣna yan ahyun patyana ng Korawa, tanpaçeșa niyata de nira: "hoe zou hij niet in staat zijn, (hen) te dooden, zij allen zijn blijkbaar als vuurvliegen, die zich in een lamp storten. Als koning Kṛṣna de Kaurawa's wil dooden, zal hij er zeker geen overlaten.»

J. fol. a, 64 , r. 1: Tam twam prâthayase mangdo wâlaç candramasam yathâ.

S. $4401 a: \ldots$ prârthayase manda....

J. kadîkang rare sẹ̣̣̆ng magĕgwan apunggung, mahyun malape wulan ing âkâça, mangkana ta kotsâhanyu mahyun mapranga lâwan sang Keçawa: "evenals een lichtgeloovig dom kind, dat de maan in de lucht wil grijpen, zoo is uw besluit, om te strijden met Keçawa.»

J. fol. a, 64 , r. 3: Rako mam iti yat mahât manyase mâ Suyodhana,

paribuya catubuddhe grahîtum mâñ cikîrșasi.

Dl. 69. 
S. 4419: eko 'ham.... yan mohân.... mâm.... paribhûya sudurbuddhe....

J. ai sang Duryyodhana, tunggatunggal aku hị̣̆ẹnyu, aḍ̂apunggung rasikâ harah, padiwaça sâmpe ri sanghulun, mụ̂̂ha kamu ahyun migrahâku: "o Duryyodhana! Gij meent, dat ik geheel alleen ben, foei! hoe dom is dat toch! houd op, mij te minachten! gij zijt dwaas, dat gij mij wilt bestrijden.»

J. fol. a, 64, r. 4: ihewâ Pâṇ̣awậ sarwwe tathewandhakawṛṣnâyaḥ,

iha Rudraç cadityaçcâ waçawaçaç ca saharșibhị̣.

S. 4420: ihaiwa .... tathaiwândhakaw ṛ̣̣naya ḥ, ihâdityâç

ca Rudrâç ca Wasawaç ca....

J. hana sang Pâṇ̣awa ngke mangkana, sang Yadukula tuwi hanâtah masěnâha, sang hyang dwâdaçâditya mwang sang hyang ekâdaça Rudra hana ta ngke, tan adoh ikang mangaran Kṛ̣nạ, ngûniweh ta sang hyang așța Basu lâwan sang saptarṣi Waçișțhâdi, yayâparö nira mangkana : "de Pâṇ ḍawa's zijn nu hier, ook het Yadu-geslacht is ten strijde uitgerust, de 12 zonnen en de 11 Rudra's zijn hier, niet ver is hij, die Kṛṣna heet, alsmede de acht Basu's en de zeven zieners, Waçișţha enz. zij zijn dichtbij hem.»

J. fol. 64 , r. 4: tatặ sa puruṣạ̣ wyaghraḥ sarjjahâra puṇa swayam,

S. $4440 a$ :... puruṣawyâgh rạ̣ sañjahâra wapu ḥ swakam்.

J. muwah somyarûpa mahârâja Kṛ̣ṇa: »koning Kṛṣna nam weder eene vriendelijke gedaante aan.» In den Skr. tekst staat, dat hij zijn lichaam samentrok.

J. fol. a, 65 , r. 4: Râjâ carati ced dharmmam̉ nrawaswarggâya kalpyate,

sa ced adharmma carati narakaya íikalpyate.

S. 4471 :... dewatwâyaiwa kalpate,... adharmmañ .... narakâyaiwa gacchati.

J. ikâ sang mahâpuruṣa, yâwat mapagěh ing swadharmma nira, byakta kapangguh ikang swargga de nira, kunang tan tût iri dharmma ning kṣatriya, yekâmangguh narakaloka: "een voornaam persoon zal, als hij zijne plichten trouw vervult, zeker den hemel verwerven, doch wie de plichten van een kṣatriya niet nakomt, die komt in de hel.» 
J. fol. 65 , r. 1: Brâhmaṇaḥ pracaret bhakṣam kṣatriyaḥ yariphalanam,

weçyo dhanajñana kuryyât çudra tat pirawârâtam.

S. 4488:.... bhaikṣyam.... paripâlayet, waiçyo dhanârjjanaṁ... çûdraḥ paricarec ca tân.

J. lwir ning prawṛtti sang brâhmaṇa, manasya juga sira, makaswabhâwa manaḍaha puṇyadâna, yapwan sang prabhu, mangrakșa bhuwana pakěna nira, kunang ikang weçyajanma, makakarmma arjjawa mâs madwal awěly asawah sawârryagiṇa nikâ, ikang çûdrajâti, yekâ pakěna pariwâra: "het werk der Brahmanen is slechts te bedelen, hun aard is, te vragen om vrome gaven. Wat den vorst betreft, zijn taak is, de aarde te beschermen, doch de Waiçya heeft tot werk, geld te verdienen, te koopen en verkoopen en rijstvelden te bewerken, dat zijn de plichten van een Ariër, een Çudra, diens taak is het, te dienen.»

In deze O.Jav. vertaling is het eigenaardig, dat kṣatriyah wordt weergegeven door prabhu. De plichten van een waiçya worden hier meer omschreven dan in den Skr. tekst.

J. fol. 65 , r. 5: Anandana mamâjataḥ dwimatam harsawaddhana,

na mayâ twam̉ na pitrași jâta twam kwâ gato hỵ api.

S. 4498:... mamâjâta dwiṣatâm harșawarddhana,.... pitrâ ca jâtạ̣ kwâbhyâgato hy asi.

J. ai Sañjaya! ko tan hana pawehmu enak amběk, hana ko tan anaku, apan gawe harșa ning musuh, tan aku mijilakěn ko, tan bapamu makawija ko, syapa karikâ winěgil parangko: "o Sa ñjaya, gij verschaft mij geen bevrediging, gij zijt mijn kind niet, want gij maakt, dat de vijand zich verheugt, ik heb u niet ter wereld gebracht, niet uw vader heeft u tot kind. Bij wien toch zult gij uw toevlucht zoeken?»

J. fol. a, 66 , r. 1: Puram wiyate yasmata tasmât puruṣa ucyate,

tâmam ahụ nârthamahâm strîwa jiwadyate yacyah.

S. $4528 b$ en $4529 a$..... wiṣahate yasmân...., tam âhur wyarthanâmânam strîwat ya iha jîwati.

J. wěnang atah rumakșa ng pura, nâhan pasěnggaha puruṣa ring kadi ko, kunang pwa pih sinanggah puruṣawyâghra, apan hînakâya kady anakbi: "omdat hij in staat is, een stad (pura) 
te beschermen, daarom moet iemand zooals gij man (puruṣa) genoemd worden, doch hoe wordt gij een tijger onder de mannen genoemd, omdat (gij) zoo zwak (zijt) als eene vrouw.»

Deze O.J. vertaling is zeer vrij, wat het slot betreft, want in het Skr. staat: "van diengene zegt men, dat hij zijn naam ten onrechte draagt, wie hier als eene vrouw leeft.»

J. fol. a, 66, r. 3: Sañjayo nâmadhṛtya twam na ca paçyâmi tan twayam.

S. $4545 a: \ldots$ nâmataç ca ... tat twayi.

J. si Sañjaya pwa ngaranmu prasiddha pagěh, kayogyan ing mangaran Sañjaya, jaya ring rạ̣amaṇḍala, ndâ tan ko jaya ring samara: "Sañjaya is uw naam, waaronder gij bekend staat; voor iemand die Sañjaya heet, past het te overwinnen op het slagveld, doch gij overwint niet in den strijd.»

J. fol. a, 66, r. 4: Yuddhâya kṣatriyaḥ ș̣șțah Sañjayeha jayajayah,

jayam twa wadhyamâno wah prâpnotindrâsalokanâ.

S. $4592 b$ en $4593 a$ : ... jayâya ca, jayan wâ .... wâ prâpnotîndrasalokatâm.

J. prayojana ning kṣatriyajanma, maprangâmijileng raṇa , mangungsira jaya parâjaya, yapwan kaparâjaya menne, tan wurung niyata nirâmanggih kendrapadân: *het doel van een kṣatriya is te strijden en ten strijde te trekken, zijn toevlucht te zoeken bij zegepraal en nederlaag. Als hij nu overwonnen wordt, zal het niet falen, of hij bereikt zeker Indra's verblijf.»

J. fol. 66 , r. 2: Râjyabawo niw ṛtto me= S. $4603 a$ : râjyâdbhâwo .....

J. mari nghulun mahyun ing kaprabhun: "ik heb opgehouden te streven naar de koninklijke heerschappij..

J. fol. 66 , r. 3 : Çocantam anaçowantî pratinitah awandhawah,

ape te pûjitâh pûrwwam api teççuhṛdo matâh.

S. 4626: .... anuçocanti patitân iwa bândhawân, api .... te suhṛdo ....

J. ikang kadang kulawandha lâwan mitra, ri samangkana tělas pinihutangan inak amběk: "broeders, bloedverwanten en vrienden, aan hen is men gemoedsrust verschuldigd.» 
J. fol. a, 67 , r. 2: Sahasrâkșamaḥ Kunti=S. 4645b: Sahasrâkṣasamạ̣ ....

J. ai sang Kuntî, tan rare samânya iku anakta, sâkșât bhațârendra paḍa niku: "o Kuntî, uw kind is geen gewone knaap, hij is te vergelijken met god Indra.»

J. fol. a, 68 , r. 4: Kânînaç ca sahoḍhaç ca kanyâ yaç câpi jâyate,

woḍhâram pitaran tasya prâhuh çâstrawido janâh.

S. 4733: .... kanyâyâm yaç ca ........ pitaram ....

J. matangnyan karikâ rakwa de sang wihikan ing çâstra, ri denya těkânak ning kanyâ, ri samangkana rarân sang makânak kita, ndan sinanggah sahoḍhara kita, apan sinanggah mipil bapanta: "daarom immers zeggen zij, die de geschriften (wetboeken) kennen, wat het kind van eene maagd betreft, die wordt zoo genoemd, omdat het eene maagd is, die $\mathrm{u}$ tot kind heeft, doch sahoḍha wordt gij genoemd, omdat uw vader $\mathrm{u}$ aangenomen heeft, naar men meent.»

In de O.J. vertaling leze men in plaats van sahodhara: sahoḍha.

J. fol. 68, r. 1: Pâṇ̣ụ putro'si dharmmatah $=S$. 4734a: (So'si Karṇa tathâ jâtaḥ) Pâṇ ḍoh ....

J. ndan pinakânakta kita de mahârâja Pâṇ̣u, makahetu ng dharmmaçâstropadeça: "doch koning Pâṇ̣u heeft u tot zoon krachtens de leer der wetboeken.»

J. fol. a, 69 , r. 2: Kanyâ garbham̉ samâdhatta bhâskarân mâñ Janârddhanah,

a dityâwa cana cewạ jâtu sa tuwyasânjayât.

S. 4757: .... mâm Janârddana, âdityawacanâc caiwa jâtâm mâm sâ wyasarjjayat.

J. singgih mâtâ bhațârî Kuntî mětěngakěn nghulun, tinaḍah ira sake bhațâra Sûryya, bhedanya tinimpalakěn těkap nira, makahetu pakon sang hyang Âditya: "wel is waar ging mijne moeder, Vrouwe Kuntî, van mij zwanger, bevrucht door den Zonnegod, doch (ik werd) door haar verstooten ten gevolge van het bevel van den Zonnegod.»

J. fol. 69 , r. 3 : Na pṛthiwyâ sakâlayah na hiraṇyasya râçibhị ,

harṣât bhayat wâk Kowindaḥ nahṛtangkạ̣ tumutsaham. 
S. 4766 :.... sakalayâ.... suwarṇasya ....,... bhayâd .... Gowinda mithyâ kartum tad utsahe.

J. mon paripûrṇna tikang kaḍatwan, paweha sang Pâṇ̣awa, yadyapin mahâbhâra paweha rahadyan sanghulun mâs maṇik, tathâpi tar wěnang nghulun gumawayakna mithya pratijñâ ri mahârâja Kurupati, tan hana harṣa ni nghulun riko sapangugung rahadyan sanghulun de ning takut: "zelfs al werd het geheele rijk gegeven door de Pâṇ̦awa's, hoeveel goud en juweelen ook aan mij geschonken worden, toch mag ik mijne belofte aan koning Duryodhana niet verbreken, ik heb daar geen begeerte naar, hoezeer gij mij daartoe door vrees aanzet.»

J. fol. a, 70, r. 2: Asya yajñasya wettâ twam் bhawîșyati Janârddhanaḥ,

adwaryyutwañ ca te Kṛṣnah kuton asmin bhawiṣyati.

S. 4784 :.... bhawiṣyasi Janârddana, âdhwaryyawañ .... Kṛṣna kratâw ....

J. katona yajña mahârâja Duryyodhana de parameçwara , rahadyan sanghulun upakalpa ng harepa jwalita yajñakâryya: "men zal zien, hoe koning Duryyodhana geofferd zal worden door u, vorst, gij zult vóór het vlammende offervuur staan.»

J. fol. 70 , r. 2: Yadâ drakṣyasa mâm Kṛ̣ṇa sahetan Sawyasâcinâ,

punaç citis tuda tasya yajñasyâsya bhawiṣyati.

S. 4801: .... drakṣyasi .... nihatami ...,.... tadâ câsya yajñasyâtha ....

J. tuminghala ta rahadyan sanghulun ri kapějah i nghulun de ning Arjjuna, ngkâ ri madhya ning raṇa, muwah mahoma ng Dhanañjaya, apan gawaya cittasangskâra ni nghulun: "gij zult zien, hoe ik gedood word door Arjuna, daar midden op het slagveld; İhanañjaya zal wederom offeren, omdat hij de ceremonie van den brandstapel aan mij zal voltrekken.

In de O.-Jav. vertaling leze men citasangskâra in plaats van cittasangskâra.

J. fol. 70 , r. 4 : Çâstreṇa nidhanam gacchet samagram kṣatramandalam,

Kurukṣetre puṇyakâme trelokyasyapi Keçawaḥ.

S. 4808: Çastreṇa.... samṛddham .......... puṇyatame trailokyasyâpi Keçawa, 
J. samûha ning ratu ta pwa hělěm, ring těgal Kurukșetra, hilang niyama ning trelokyamaṇdala: "door de samenkomst van vorsten later, op het veld Kurukṣetra, zal de vaste orde der drie werelden verdwijnen.»

Deze verkeerde O.-Jav. vertaling is te verklaren door de verwarring van çastra en çâstra in den Skr.-tekst, waar eenvoudig staat: door de wapenen zal het geheele Kṣatriya-geslacht ten onder gaan, op het Kuru-veld, dat het heiligste is van de drie werelden, o Keçawa.

J. fol. 71 , r. 1: Swapnâ hi bahawio ghorah dṛçyante Madhusudanah,

nimittâni ca ghoraṇam tathotpâtâh sudaruṇaḥ.

S. 4838: .... ghorâ .... Madhusûdana, ... ghorâni .... sudâruṇ̂h

J. makweh ikang ipyan mahala, cihna ning açubhanimitta tělas katon, wastwâpûrwwa ikang mahotpâta: "talrijk zijn de booze droomen, teekenen van slechte voorbeduiding zijn gezien, ongehoorde dingen, die groote rampen voorspellen.»

J. fol. 71, r. 4: Sahasrapâdami prâsâdami swapnânte ku Yudhișțira,

adhirohan taya dṛțah saha bhrâtṛrir acyute.

S. 4862: .... sma Yudhiṣthiraḥ, .... mayâ .... bhrâtribhir acyuta.

J. kunang sang Yudhișthira tinon i nghulun manek ring prâsâda makanganak sewu sira ring pangipyan, saha wwang sânak nira kabeh: "Yudhișțira echter heb ik in mijn droom gezien, hoe hij een toren met duizend treden besteeg, met al zijne broeders. »

J. fol. 72 , r. 4: Patya doșan drawi yaddhi tathâ 'yuddhe parâbhawam ,

adhanasya mṛtam çreyaḥ na hi jñatikṣaye jayah.

S. 4897: paçye doṣam dhruwam yuddhe..., .... çreyo …‥jũâtikṣayo....

J. tonanta hala ning yuddhakâryya ginawe, niyatâgawe kâlaha, ya ikâ ngganya katon de kakanta mahârâja Dhṛtarâșțra, matangnyan inak pějah ing daridra hînajana, sangka ring rạ̣a yan pakaphala ng wandhawakșaya: "zie de slechtheid van het oorlogvoeren, dat veroorzaakt stellig, dat men overwonnen 
wordt, dat wordt gezien door uwen ouderen broeder koning Dhṛtarâșra, want het is beter, dat men als een arm man van geringe geboorte sterft, dan te overwinnen op het slagveld, wanneer dit ten gevolge heeft, dat het geslacht te gronde gaat.»

J. fol, a, 73, r. 3: Kopito bhagawân yatra Durwâsâ me waran dado,

ahonan dewasangyuktam wâsatyah pitṛweçmani.

S. $4903 b$ en 4904a: Toṣito.... waram dadau, âhwânam mantrasaṁuktam wasantyâḥ....

J. ngûni harah kâla ni nghulun rarâ, kawuyungan nghulun de bhagawân Durwâsâ, kunang de ni kabhaktin i nghulun, dadi sirâweh anugraha wěkasan, wěnang pangârâdhana dewatâ lwir ning dhûpamantra paweh nira, yadyapin tamolaha ri dalěm gṛha magaway ârâdhana: "vroeger toen ik nog maagd was, werd heer Durwâsâ vertoornd op mij, doch door mijne aanhankelijkheid geschiedde het, dat hij mij ten slotte een gunstbewijs schonk, waardoor ik in staat was, de goden tot mij te roepen door een wierookformulier, dat hij mij gaf, zelfs terwijl ik vertoefde in huis, (kon ik) die aanroeping doen.»

J. fol. 73 , r. 2: Yo ço kânînagarbho me putrawat pariwarttitah,

tasmat na kuryya wacanam patyam pitṛhitan tathâ.

S. $4909 b$ en $4910 a$ : Yo 'sa u.... parirakșitah, kasmân na kuryyâd.... pathyam bhrâtṛhitami...

J. ikâ sang Karṇṇa prasiddhânak ni nghulun kâla ning rarâ kěta rasikâ, nda nyayânak ni nghulun sakurěn hị̣̌p ni nghulun an huwus matuha, ring kapana tikâ pisinggiha sojar i nghulun apan hitâwasâna magawaya suka ri sang matuha: "deze Karṇṇa is ongetwijfeld mijn zoon, (ontvangen) toen ik nog maagd was, en mijn zoon behoort mijn gevoelen te deelen, nadat hij volwassen geworden is. Hoe zou hij mijne woorden (niet) gehoorzamen, want zij zijn nuttig van uitwerking en zullen zijnen ouders vreugde verschaffen.»

Het woord voor "niet" ontbreekt in de O.-J. vertaling.

J. fol. a, 74, r. 1: Wruhi kim kârawâni te=S. $4917 b$ ult.: brûhi kim karawâni te.

J. mâjara ta rahadyan sanghulun, patik mahâdewî suddhyâ ya sumiddhâkna ya: "deel het mede, ik zal trachten, het tot stand te brengen.» In het Skr. staat: spreek, wat kan ik voor u doen? 
J. fol. a, 74 , r. 1: Konteyas twa na Râdeyah na ca wâdirataḥ pitah ,

nâsmi sûtakule jâtạ̣ Karṇṇa tad widi me wasâ.

S. 4918: Kaunteyas twam na Râdheyo na tawâdhirathạ pitâ, nâsi.... Karṇṇaitad widdhi me wacah.

J: kita pih bapa, anak ning Kuntî tika laki, tan anak sang Râdha, $\tan$ bapanta sang adhiratha, apan nghulun anaku tan wěkawěka ning sûta kawwanganta, kaniçcayâkěn saçabdangku: 'gij mijn waarde, zijt de zoon van Kuntî, niet de zoon van Râdha, uw vader is geen wagenmenner, want ik mijn kind, stam niet af van een wagenmenner, vertrouw op al mijne woorden. »

J. fol. a, 74 , r. 2: Kaninas twa mayâ jâtaḥ pûrwwajaḥ kukṣiṇâ dhṛtah,

Kuntirâjasya bhawane Pârthas twam asi putraka.

S. 4919: Kânînas twami....,.... jâtas....

J. kita anaku, anak ni nghulun ngûni rarâ kita, prasiddha tuha rumuhun winětěngakěn, kawijilanta ryy umah ni bapa ni nghulun mahârâja Kuntibhoja, sangkșepanya, wěnang sinanggah Pârtha kitânaku, apan anak ni nghulun kita tuhu-tuhu: "gij mijn kind, zijt de zoon van mij, vroeger toen ik nog maagd was, gij zijt klaarblijkelijk de oudste, omdat gij het eerst ontvangen zijt, gij zijt geboren in het huis van mijn vader Kuntibhoja, kortom, gij zijt gerechtigd, om Pârtha genoemd te worden, omdat gij inderdaad mijn zoon zijt.»

Uit de O.J. vertaling blijkt, dat de Skr. tekst, dien de vertaler voor oogen had, inderdaad Pârthas had, waar de Calcutta-editie jâtas heeft. In de editie staat Pârthas eerst in vers 4928b. Eigenaardig is het, dat Kuntî's vader hier reeds Kuntibhoja heet, evenals in de Nieuwjavaansche lakon's. Dit bhoja schijnt eene verbastering van râjâ te zijn.

J. fol. a. 74 , r. 3: yo 'yan dewo Wirocanah $=$ S. $4920 a$ ult.

J. sang hyang Âditya prasiddha mangdadyakěn kita: "de Zonnegod heeft u voorzeker verwekt. »

J. fol. a, 74 , r. 3 : Kuṇ̣alâ baddhakawacạ̣ dewagabha çriyâwṛtah.

S. 4921a: kuṇdalî baddhakawaco dewagarbhaḥ....

J. makuṇdalakawaca, kinasut ta kita de ni tejomaṇdala: "met ringen en gepantserd, gij waart gehuld in een lichtkring.» 


\section{J. fol. a, 74 , r. 4 : Jâtas twam asi durdarṣah $=$ S. $4921 b$ .... durdharṣo.}

J. matangnyan agöng prabhâwanta mangke $\mathrm{n}$ atuha: «daarom zijt gij nu zeer machtig, nu gij volwassen zijt.»

J. fol. 74 , r. 2: çalyam âha Pṛthâ wâkyam Karṇṇa mâtṛwacaḥ çṛ̣uh,

çrewyas te syân narâwyâghraḥ sarwwam awaratas tatah.

S. 4930: Satyam.... kuru, çreyas.... narawyâghra.... âcaratas tathâ.

J. ahânaku sang Karṇṇa! tuhu singgih iku çabdenujarakěn dewî Kuntî, haywa tatan pisinggih ikâ yatanyan çâçwatâmanggihenak kita: "O mijn zoon Karṇna! Inderdaad waar zijn deze woorden, die Kuntî tot u zegt, wees er niet ongehoorzaam aan, opdat het u voortdurend wel moge gaan.»

J. fol. a, 75, r. 2: Mayâ plawena sanggrame tatiṣâtir apatyayam,

tyajayen tân ahan katam apare kâyajayaç ca.

S. 4942 :.... sanggrâmam titîrṣanti duratyayam, apâre pârakâmâ ye tyajeyam tân aham katham.

J, sang Korawa mahyun měntasana ng samara kângkěn tasik tanpatěpi, yapwan durggama, tatan hana hinarěp-harěp waneh, mârgga ning wěnangâměntasa bheda sangka ri nghulun kângkěn banawa, atinggala kětikâ patik haji ri sang ahyun měntasa, alib mara hala nikâ: "de Kaurawa's wenschen het slagveld over te steken, dat te beschouwen is als een zee zonder oever; als er echter moeilijkheden zijn, is er niemand anders, op wien zij vertrouwen, om te kunnen oversteken, behalve ik, die te beschouwen ben als een schip; als ik nu hen verliet, die wenschen over te steken, zou dit toch wel zeer slecht zijn.»

J. fol. 75 , r. 1: Kṛ̣ṇena sâhitak to ca nasyate ca Dhanañjayât,

ko 'dya bhidyan na mâm widyât Pârthânâm samiting gatam.

S. $4937: \ldots$ sahitât ko wai na wyatheta ..., ... bhî̀tam .... samitim ....

J. hana ta wwang tan arěs matakuta, yan tona Dhanañjayâdulur Kṛṣna těngah ning raṇa, ri samangkananya tuwi, ndya ng wwang 
ta niçcaya pih ri tan takut ikang Karṇṇa harěpakna ng Pâṇdawa sakulagotra: "Is er iemand, die niet vervaard en bevreesd is, als hij Dhanañjaya vergezeld door Kṛ̣nna midden op het slagveld ziet? Als dit zoo is, hoe zou iemand dan zeker zijn, dat Karṇna niet bevreesd is, de Pâṇ̣awa's met hunne îamilie tegemoet te treden?»

Hier valt eene kleine verandering in de volgorde van de verzen van den Sanskṛttekst, vergeleken met die in de Calcuttaeditie waar te nemen, daar op vers 4942 vers 4937 volgt.

J. fol. a, 76 , r. 3: Duryyodhana niwodenam kulârthe yan rawimi te,

tac cutwâ Kuruṣâdulâ swakulasya hitam kuru.

S. $4972: \ldots$. nibodhedam.... yad brawîmi...., ... chrutwâ râjaçârdûla....

J. ai sang Duryyodhana! Haywa kamu wihang pituhûjarku, apan kahaywakna ning kula donanya, rěngwakěn i sawuwus damělakěn suka ning sakulagotra: "o Duryodhana! Aarzel niet te gehoorzamen aan mijne woorden, want zij hebben het welzijn van de familie ten doel. Luister naar al (mijne) woorden en behartig het geluk van (uwe) familie.»

J. fol. a, 77, r. 2: Andhah karaṇahinehi nâwe râjâ pitâ twacca,

râjâ suya pâṇ̣awawat mahâtmâ lokawiçrutah.

S. $4996 b$ en $4997 a: \ldots$ hînatwân naiwa.... tawa,... tu Pâṇụ r abhawan....

J. kunang apan mijil wuta sang bapanyu, wikâlendriya ngaran ikâ, nâhan matangnyan tan rinatwakěn, sang Pâṇ̣u ta ratu wěkasan, sulakșaṇa hana ring loka: "Doch omdat uw vader blind geboren werd, dat heet met gebrekkige zintuigen, dat was de reden, dat hij niet tot vorst verheven werd. Pâṇ ụu werd ten slotte koning, goed bekend in de wereld.» Onmiddelijk daarop volgt:

Sa râjâ tasya we putra pitur dhayadyaharina $=\mathrm{S}$. $4997 b$ :... te putrâh.... dâyâdyahâriṇah.

J. sang Pâṇụu prasiddha ratu, hana pwânak nira rasika Pâṇḍawa, ring kapana tika tan dadya panglilirana kaḍatwan: "Pâṇ ḍu was ongetwijfeld vorst, zijne zonen nu zijn de Pâṇawa's. Hoe zouden zij het rijk niet erven?» 
J. fol. a, 78, r. 2: Ko 'yam Duryyodhano namah kule 'smin kulawasanah,

yasya lobhâbhibhûtasya matim sarwwânuwattate.

S. $5021 b$ en $5022 a$ :... nâma.... kulapâmánahạ, tas ya.... samanuwarttase.

J. syapa ta ngaran Duryyodhana karih, wěnang angrakșa wangçasantana, bheda sangkeng rumakṣâkna kula purih nikâ, apan lobhișțha hatinya, harah tinûtakěn sakâmběknya de rahadyan sanghulun: "Wie is hij toch, die Duryyodhana heet? $\mathrm{Hij}$ is in staat, zijn geslacht te beschermen, doch in plaats van te streven naar het beschermen van zijn geslacht, omdat zijn hart zeer begeerig is, volgt gij helaas al zijne begeerten.»

J. fol. a, 79 , r. 1: Somaḥ prajâpati pûrwwam Kurûṇ̂ạ wangçawandhanah ,

semât babhûwa pașto we Yayâtir Nahuṣâtmajạ̣.

S. 5042: .... prajâpatị̣ .... wa ṁçawarddhanaḥ, so mâd .... șaṣṭho'yam ....

J. ngûni tambay ning ratu, sang hyang Soma sirâdi mangrakșa prajâ, sira ikânṛști Kuruwangça, yadyapi katěka mangke, kaping něm ri sâna(k) nira mahârâja Yayâti ngaran ira, anak mahârâja Nahușa: "vroeger was de eerste der vorsten de Maangod, hij beschermde het eerst zijne onderdanen, hij schiep het Kurugeslacht, dat tot nu toe bestaat. De zesde van zijne nakomelingen heette koning Yayâti, de zoon van koning Nahuṣa.»

J. fol. a, 79 , r. 2: Tasya putrâ babhûwasya bañca râjarșisaptamaḥ.

S. $5043 a$ : ... babhûwur hi pañ ca râjarșitattamâh.

J. mahârâja Yayâti sira mânak limang siki, pinakawiçeșa ning râjarși : "koning Yayâti kreeg vijf kinderen, die voortreffelijke koninklijke zieners waren.»

J. fol. 79 , r. 1: Tathewa sarwwadharmmajñah pitu mahâ pitâmahạ̣,

Pratîpạ pṛthiwitalah triṣu lokeṣu waçrutah.

S. 5053: Tathaiwa $\ldots$ pitur mama ........ pṛthiwîpâlas .... wiçrutah.

J. sira sang yuyutku sakeng sira bapa rakwa, mahârâja Pratîpa ngaran ira, dharmakâri rakwa sira, sobhâgya ring tribhuwana: 
"de overgrootvader van mijn vader, koning Pratîpa genaamd, was deugdzaam, zegt men, en beroemd in de drie werelden.

Het woord yuyut in de O.-J. vertaling is de vertaling van Skr. pitâmaha.

J. fol. a, 80 , r. 3: Yudhișțhiro râjaputraḥ mahâtmâ râjamahati nyâyâgatam râjyam idam bhunaktinûjạ̣ sadâ.

S. $5072 a: \ldots$ râjaputro .... idañ ca tasya. Het woord râjamahati en de laatste woorden bhunaktinûjạ̣ sadâ ontbreken in de Calcutta-editie.

J. ikâ sang Yudhișțira yukti muktya ikang kaḍatwan, saha lâwan wwang sânak rasikâ, apan sarika sâkșât râjaputra, tuwi paripûrṇṇa lakṣaṇa: "deze Yudhișțhira behoort de koninklijke waardigheid te verkrijgen, met zijne broeders, want zij zijn als koningszonen en met volmaakte geluksteekenen.»

J. fol. a, 80 ,r. 4 : Çâstren swito bandhujanasya sâdhuḥ, priyaḥ prajânâm sukṛ̂lonakampi jitendriyaḥ sâdhujanasya bharttâ, kṣamâ titikṣâ dama ârjawañca.

S. $5073 a$ ult. tot $5074 a$ : Çâstre sthito ......... suhṛ̂ânukampî....

J. wihikan mangaji, sâdhu ring kulawargga, kinahyunan ing rât kabeh, masih ta ring priyamitra, wěnang ta umalahakěn indriya, rakṣaka ri sang sajjana, maharddhika upaçama, tan göng krodha: "geleerd te zijn, goed jegens zijne bloedverwanten, bemind door iedereen, zijnen geliefden vrienden genegen, in staat om zijne zintuigen te bedwingen, de goede menschen beschermende, edel van aard en tot gemoedsrust gekomen zijnde, niet hevig in zijne begeerten.»

De O.-J. vertaling van het Bhagawadyânaparwa "loopt tot fol. a, 81 , r. 3 en bevat 49 palmbladen tegen 2516 verzen in den Sanskṛt-tekst.

\section{SAINYANIRYânAPARWA.}

J. fol. 81 , r. 4: Waddhârwa yah samûtparṇaḥ Sikaṇḍi Drupadâtmajạ̣,

sadanti siddhâ râjendraḥ ṛ̣ayaç ca samâgatâh.

S. 5126: Wadhârtham .... samutpannạ̣ Çikhạ̣ḍ̂....., wadanti .... râjendra ....

1 Vgl. over den inhoud van dit parwa Holtzmann, o. c. p. 111-115. 
J. sang âryya Çikaṇḍi pinakânak mahârâja Drupada, matyana bhagawân Bhîșma rakwa don ira mijil, pâjarajar sira sang siddha maharși sira kabeh: "de edele Çikhạ̣ḍ̂, de zoon van koning Drupada, is geboren met het doel, om heer Bhîṣma te dooden, zoo zeggen de zieners en groote wijzen allen».

J. fol. a, 82 , r. 2 : Kṛtâsto kyaḥ kṛtâsto wâ wṛddho wâ yadi wâ yawa.

S. 5131b: kṛtâstro 'py akṛtâstro.... yuwâ.

J. mon wihikana ring astra, mon tan wihikan, mon atuha, mon rare tuwi: "of hij bedreven is in de wapens, of niet bedreven, of hij oud is, of zelfs een knaap.»

J. fol. a, 82 , r. 3: ema no wijayo mulam $=$ S. $5132 a$ : eșa no wijaye mûlam.

J. sabarinyan mârgga ning kawijayanta pwa ya: "mits hij slechts de weg (aanleiding) is van onze overwinning.»

J. fol. a, 82 , r. 4: Nâ Darttarâșțra çakṣyanti sthâtu dṛțta Dhanañjaya,

Bhîmasenañca sakrudam yamo bhâpi Yamopamo.

S. $5142 b$ en $5143 a:$ Na Dhârtarâșțrâh .... sthâtum dṛsțtwâ Dhanañjayam, ,... samk suddham yamau câpi Yamopamau.

J. ikang Korawakula kabeh tan wennang niyamanyânghera těngah ning palagan, sabarinyân tona sang âryya Dhanañjaya humarěp, astam sang âryya Wṛkodara, yady api sang Nakula Sahadewa tuwi : "het geheele Kuru-geslacht is niet in staat, zich te bedwingen of stand te houden midden op het slagveld, als het den edelen Dhanañjaya voor zich ziet, laat staan den edelen Wṛkodara, of ook zelfs Nakula en Sahadewa.»

De O.Jav. vertaler heeft wel begrepen, dat onder de yamau (tweelingen) Nakula en Sahadewa te verstaan zijn, doch Yamopamau (op Yama gelijkende) laat hij onvertaald.

J. fol. a, 83 , r. 2 : Tâsmin heto deçe sagḍah prabhûtayawasenwaneh,

niweçayâm âsa tadâ sena râjâ Yudhiṣṭhirah.

S. 5170: Tato deçe same snigdhe prabhûtayawasendhane,.... senâm ....

J. ri pradeça nikang Kurukșetra hana ta lěmah maratâhayu, makweh tạ̣ahnya saha gangan kayunya, ngkâ tikang watěk 
Pâṇ̦awa $\mathrm{n}$ dinunungakěn těkap mahârâja Yudhișthira: in het gebied van Kurukṣetra was een vlak schoon stuk grond, met veel voedsel en groenten en boomen, daarheen werden de Pâṇdawa's gevoerd door koning Yudhișțhira.»

J. fol. 83, r. 3: Akṛtenawa kâryyeṇa gataḥ Pârthân adhokṣajah,

sa henyan ahumarișțo druwam dakṣaty asangçayaḥ.

S. 5196: Akṛtenaiwa....,.... enân manyunâ wișțo dhruwam dhakṣyaty asamçayam.

J. rěngwaknâtah rahadyan sanghulun katiga, ikang Kṛṣ̣̣a kětâ ya, prasiddha tan siddhakâryya ta ngaran ikâ mangke, mantuk tika mare sang Pânḍawa majar-ajar, byakta ta ya krodhânggěsěngane ri kita: «luistert gij drieën! Van Kṛṣṇa kan men nu met recht zeggen, dat hij niet geslaagd is in zijn taak, hij is teruggekeerd naar de Pâṇawa's, om te berichten, zeker zal hij in zijn toorn u verbranden.»

J. fol. a, 84, r. 1: Âsannajalakâșțhâni çataso 'tha sahasraça,

acedyaharamârggani randocayayutani ca.

S. $5202: \ldots$ sahasraçaḥ, acchedyâhâramârgâṇi bandhocchrayacitâni ca.

J. subhikṣa ta ya ring wwai lâwan kayu, tan pĕgata hawana ning taḍah těkeriya: "waar overvloed is van water en hout, waarheen de toevoer van voedsel niet afgesneden kan worden.»

J. fol. 84 , r. 4: Na wa Bhîṣmasya durmmeda tṛnota Widurasya ca,

mama wâ bhapitam kiñcit sarwwem ewâtiwarttate.

S. 5223: Na ca .... durmedhâh çṛnoti.... wâ,.... bhâșitam .... sarwwam ....

J. iking Duryyodhana ngaranya, nora kěta pinituhunikâ, tan bhagawân Bhîșma, tan âryya Widura, astam tojar ni nghulun, pisaningû ikâ humiḍẹpa ya, apan durmedha pinakaswabhâwanya: "deze Duryyodhana geeft geen gehoor aan heer Bhîșma, of aan den edelen Widura, laat staan aan mijne woorden. Hoe zou hij die ter harte nemen, want hij is van nature onvatbaar voor overreding.» 
J. fol. 85 , r. 3: Rathasyasyan daça gajạ̣ gajasya daça wâjina h,

narah daça haheç casan padarâksa samantatah.

S. 5264: Rathasyâsan .... gajâ ...., narâ .... hayasyâsan pâdarakṣậ ....

J. ikang rathâsiki dinulur de ning liman sapuluh, ikang gajah sapuluh ikang sasiki-sasiki dinulur de ning kuda sapuluh, ikang kuda sasiki dinulur de ning padâti sapuluh, pinakapâdarakṣa kanan keri: "een wagen was vergezeld door tien olifanten, ieder van die tien olifanten was vergezeld door tien paarden, ieder paard was vergezeld door tien voetknechten, die het links en rechts te voet bewaakten.»

J. fol. 85, r. 4: Rathasya gajạ pañcâçat nâgasya çata wâjinaḥ,

hayasya puruṣậ sapta bhinnâsaddhânakarinaḥ.

S. 5265: .... nâgâh pañcâçan nâgasyâsan çatami hayâh, .... bhinnasandhânakâriṇah.

J. hana ratha tunggal dinulur de ning liman limang puluh, ikang liman sasiki dinulur de ning kuda sâtus, ikang kuda sâtus sasikinya dinulur de ning pâdâti pitung siki, apa pakěna nikâ, ya ta pinakapaněpung yan huwus pĕgat de ning musuh: "een wagen was vergezeld door vijftig olifanten, een olifant was vergezeld door honderd paarden, ieder van die honderd paarden was vergezeld door zeven voetknechten. Waartoe dienden die? $\mathrm{Zij}$ dienden om te binden, wanneer er een afgesneden was door den vijand.»

J. fol. a, 86, r. 1: Senâpañcaçatanyahụ rathạ̣ tawâta kahetu,

daçasenaçca prathanah pṛtanâ daçawâhinî.

S. 5266: Senâpañcaçatam nâgâ rathâs tâwanta ewa ca, daçasenâ ca pṛtanâ ....

J. ikang ratha limang atus ndan kadi kramanya ngûni dinulur de ning liman sapuluh ring sasiki, yeka sinanggah sasenâ ngaranya, ikang sapuluh senâ, ya saprttanâ ngaranya, ikang sapuluh pṛtanâ, ya ta sawâhiní ngaranya: "de 500 wagens, zooals vroeger de regeling was, werden ieder vergezeld door tien olifanten, dat werd eene senâ genoemd, tien senâ's heette eene pṛtanâ en tien pṛtranâ's eene wâhinî.» 
J. fol. a, 86, r. 2: Wâhiṇi pṛthanâ senah wajini daçatah camûh,

akṣohiṇi wa paryaya niruktâ ta wurutini.

S. 5267: Senâ ca wâhinî caiwa pṛtanâ dhwajinî ...., akṣauhiṇî tu paryâyair .... ca warûthinî.

J. ikang sawâhinî mwang sapṛtanâ lawan sasenâ ya ikâ sinanggah sadhwajinî, ikang sapuluh dhwajinî, yekâ sacamûh ngaranya, ikang sapuluh camûh ya sâkșohinîi ngaranya, sawarûthinî ngaranya waneh: "eene wâhinî en eene prtanâ en eene senâ, dat wordt eene dhwajinî genoemd, tien dhwajinî's, dat heet een camûh, tien camûḥ's, dat heet eene akṣauhiṇî of ook wel eene warûthinî̀,

J. fol. a, 86 , r. 4: Narânâm pañcasadeçam patinâma widhîyate,

senamukañca tipras tu gulma ity abhisajñikah.

Daça gulmo gaṇaç casit gaṇas tw ayutaço bhawet,

Duryyodhanasya pehahuh yotsyahanah prahâriṇah.

S. 5270 en $5271: \ldots$ pañcapañcâçad eșa pattir...., senâmukhañca tisras tâ.... abhiçabditami, trayo gulmâ gaṇas tw âsît......... senâsu yotsyamânâh....

J. hana pâdâti limang puluh, yekâ sapatti ngaranya, kunang ikang sasenâ pinintigâkěn, yekâ sagulma ngaranya. Ikang sapuluh gulma, ya sagaṇa ngaranya, ikang sâyuta gaṇa, yatika pinakawadwâ sang Duryyodhana, mahâçakti paprang ikâ kabeh: "vijftig voetknechten, dat heet een patti, doch eene senâ driemaal genomen, dat heet een gulma. Tien gulma's, dat heet een gaṇa, en 10.000 gaṇa's, zoo sterk was het leger van Duryyodhana, allen machtig in den strijd.»

J. fol. a, 87 , r. 2 : Raçmiwacaçâm idityaḥ wîrudhâm iwa candramâh,

Kuwera iwa râkṣaṇam mâruta iwa pâwakah.

S. 5289: raçmiwatâm iwâdityo ..... .... yakṣậâm dewânâm iwa wâsawah.

J. ring sarwwateja kabeh sang hyang Âditya sira lwih, ri sakweh ning kayw aruhur sang hyang wulan pinakaçaraṇa nikâ, yapwan yakṣa kabeh, sang hyang Waiçrawaṇa mrĕmânerika, i sakweh ning watěk hyang sang hyang Pâwaka pinakâdikâra ngkâna: "onder alle (hemel)lichten is de Zonnegod de voorDl. 69 . 
naamste, alle hooge boomen zoeken hunne toevlucht bij den Maangod, wat echter de Yakșa's betreft, hun aanvoerder is Kuwera, van alle goden is de Vuurgod de voornaamste."

Uit de O.J. vertaling blijkt, dat het laatste woord van het Skr.-vers inderdaad pâwakaḥ was en niet Wâsawaḥ, zooals de Calcutta-editie heeft. In plaats van mrěmânẹikâ leze men: pramânerika.

J. fol. 87, r. 3: Karṇṇo wâ yudhyatâm pûrwwam aham wâ pṛthiwîpate,

sparddhate hi sadrâtyatham sûtaputro mayâ rạ̣e.

S. $5301: \ldots$ sadâ 'tyartham ....

J. ikang Karṇṇa pwa kon mapranga rumuhun, kasulâkujukșarâku rumuhuna, tan parěnga lâwan ikang Karṇṇa, apak sadâ pahingan yâwat ring raṇacarita, kumwa wuwus nikang sûtaputra: "gelast Karṇna het eerst te strijden, of laat ik in het tegengestelde geval(?) voorgaan, laat ik niet tegelijk strijden met Karṇna, want ik ben altijd onbegrensd in het oorlogvoeren. Zoo sprak de zoon van den wagenmenner.»

Voor kasulâkujukṣara in de O.-J. vertaling leze men misschien: kasulaya pakṣa, beantwoordende aan Skr. wâ (of). Hier is de tekst zeer corrupt. Onmiddellijk daarop volgt:

Aham jîwati Ganggaye yota rajanman katañjana, athe Bhîṣme ca yotsyâmi saha Gạ̣diwadanwanâ.

S. 5302: Nâhami... Gânggeye râjan yotsye kathañcana, hate... tu.... Gâṇ̣̂îa dhanwanâ.

J. pisaningû kětâku mapranga, yan hana hurip nikung Bhîșma? Kunang yan huwus pějah ikang Bhîșma, irikâku n lěkasâprang lâwan ikang Dhanañjaya: "Hoe zou ik strijden, wanneer Bhîṣma hier nog leeft? Doch als Bhîșma gesneuveld is, dan zal ik ten strijde trekken tegen Dhanañjaya.»

J. fol. a, 89 , r. 3: Ubho çișyo hi me wiro gaddhâyuddhawiçarado,

tulyasneho hyahâ Bhîme tatâ Dûyodane nrape.

S. $5346 b$ en $5347 a$ : Ubhau çiṣyau.... wîrau gadâyuddhawiçâradau, .... 'smy ato.... tathâ Duryyodhane nṛpe.

J. rasiki sang rwang siki âryya Wṛkodara mwang sang Duryyodhana, kapwa çișya ni nghulun ikâ ri gadâyuddha, kapwa kasih ni nghulun, tan hana kapakṣapâta salah sasiki: "deze 
beiden, de edele Wṛkodara en Duryyodhana, zijn beiden leerlingen van mij in den strijd met knotsen, beiden heb ik even lief, ik ben niet partijdig jegens een van hen beiden.»

J. fol. 89 , r. 2 : Sahâyo 'smi sthito yuddhe yadi bhîto 'si Pândạa.

S. 5370b: sahâye 'smin....

J. sang âryya Dhanañjaya, yan hana takuta ring rạ̣a, nghulun hana sahâyanta: «edele Dhanañjaya, als gij bevreesd zijt in den strijd, zal ik uw helper zijn.»

J. fol. 90 , r. 3: Ya âtmano duçcabhitat âçubha prâpnuyât narah ,

enasânasa deçan wâ kâlami wâ gakgamitu mâhât.

S. $5399 b$ en $5400 a$ :... duçcaritâd açubham prâpnuyân..., na sa kâlami na wâ daiwam̉ waktum etad ihârhati.

J. ikang wwang mamangguh hala, makanimitta hala nikang karmma ginawe ni çarîranya ngûni, ikâ ta wwang mangkana, pisaningû tikang dewatâsiheriya, mwang mangguha ng pâpa, makahetu göng nikang karmmâhala ginawe: "iemand, die leed ondervindt ten gevolge van slechte daden, die zijn lichaam vroeger verricht heeft, hoe zouden de goden zulk een man lief hebben, en hij zal rampen ondervinden ten gevolge van de massa van de verrichtte slechte daden.»

In den Skr. tekst staat, dat men de gevolgen van eigen slechte daden niet moet toeschrijven aan den tijd of het noodlot.

J. fol. a, 91, r. 1: Na hy ema kataḥ puruṣạ̣ karmmaṇoh çubhapâpayoh,

açatantro hi puruṣah kâryyate dârupuruṣaḥ.

S. $5404 b$ en $5405 a: \ldots$ ewa karttâ...., aswatantro.... dâruyantrawat.

J. ikang janma wwang ngaranya kadi ya ta ikang gumawaya hala lâwan hayu, tuhun hana molah inulahakěn, ya gatinya, paramârtha nikang janma mânuṣa, tan swatantra ri kâwakanikang wakanya dharmma mânuṣa, apa tar wěnang ḍumâhani çarîranya, gawaynya hala mwang hayu, kadi hiněb ning lawang mara padanya wěkasan: "het is alsof de mensch (zelf) goede en slechte daden verricht, doch hij beweegt zich en wordt bewogen; de aard van den mensch is, dat hij niet zelfstandig is in zijne handelwijzen(?), want hij is niet in staat(?) zijne hande- 
lingen zijn slecht en goed, evenals het sluiten van een deur is het, om zoo te zeggen, ten slotte met hem.»

De O.Jav. vertaling is zeer corrupt. Wat ḍumâhani, en kâwakanikang wakanya, moet beteekenen, weet ik niet.

- Mara is "om zoo te zeggen", ongeveer Skr. iti. In den Skr. tekst staat: want de mensch is niet zelf de bewerker van zijne goede en slechte daden, want de mensch handelt onzelfstandig, evenals een houten machine (rad).

Hier eindigt de O.-J. vertaling van het Sainyaniryânaparwa '. Het bevat 10 folia tegen 309 verzen in den Skr.-tekst (çl. 5097-5406).

\section{ULûKADÛTâGAMANAPAKWA.}

J. fol. a, 91. r. 3: Hiraṇwatya cinișțeșu Pâṇ̣aweṣu mahâtmasu,

Duryyodhana mahârâja Karṇnena saha bhaṣata.

S. 5407a en 5410b: Hiraṇwatyâm niwișțeșu...., tatra Duryyodhano râjâ.... Bhârata.

J. sẹ̣̣̆ng umentas ring lwah Hiraṇwatîkâ sang Pâṇạawa, irikâ ta rânak aji mahârâja Duryyodhanângucap mwang mahârâja Karṇṇa: "terwijl de Pâṇḍawa's de rivier de Hiraṇwatî overstaken, sprak de koningszoon vorst Duryyodhana met koning Karṇna.»

Uit de O.-J. vertaling blijkt, dat in de door den vertaler gebruikten tekst werkelijk stond: sâhâbhâșata in plaats van saha Bhârata.

J. fol. 91, r. 3: Asmân wâ twam̉ parâjitma praçati pṛthiwîm imâm,

athawâ niyato 'smabhị dewalotang gamasyasiḥ.

S. $5487 b$ en $5488 a: \ldots$ parâjitya praçâdhi...., .... nirjito. 'smâbhî rạ̣e wîra çayiṣyasi. Het in den O.J. tekst geciteerde Skr. vers moet aldus verbeterd worden:... nihato 'smâbhir dewalokam gamiṣyasi (of gij zult, door ons gedood, naar de godenwereld gaan).

J. yan alaha sanghulun Korawa denta, byakta kita tumunggalakěn kabhuktyan ikang pṛthiwîmaṇḍala, yapwan alah kita de sanghulun Korawa, swarggaloka ikâ kabhuktya denta: "als wij,

1 Zie over den inhoud Holtzmann, o.c. p. 115. 
de Kaurawa's, door u overwonnen worden, zult gij klaarblijkelijk het genot van de aarde alleen bezitten; als gij echter door ons, de Kaurawa's, overwonnen wordt, zal de hemelwereld door u genoten worden.»

J. fol. a, 92, r. 4: Puṣțâste 'çwâ bhṛtah çûrah çwo yuddhaswa sakeçawah,

asamâgamya Bhismeṇaḥ saṃuge kim wikașțake.

S. $5500 b$ en $5501 a: \ldots$ bh ṛ̂tâ yodhâh .... yudhyaswa...., .... Bhîșmeña.... wikatthase.

J. luměkas kita huwus makasahâya mahârâja Kṛ̣̣na, tapwan wěnang mamapag bhagawân Bhîșma ring raṇa, pisaningû ta kita kastawâ ring loka: "ga gij op weg, met koning Kṛ̣ṇa als helper, zijt gij nog niet in staat, om heer Bhîșma in den strijd te weerstaan. Hoe zoudt gij geprezen worden in de wereld?»

J. fol. a, 93, r. 4: Yady utpatasi lotam prit dadyah wiçasi bhûtalam,

tatâh tatrârjjunaratham prabhâte drakṣyase 'gratah.

S. $5640: \ldots$ lokâmi trîn yady âwiçasi...., tatra.... ....punah.

J. yadyan bonglota ko mara ring trilokamaṇḍala, sumilěma ri silěm ning Ganggâ kunang, mahöthětana ring pâtâla, katona juga ratha sang Arjjuna yan sakatambe mesuk: "als gij de drie werelden uitvliegt, of onderduikt in de diepte van den Ganges, of $u$ verbergt in de hel, toch zal de wagen van Arjjuna zich vertoonen in den vroegen morgen.»

J. fol. 93 , r. 1: Sawîryya yah samâçritya samâhwayati we parân,

abhitah puraya çaktim sa we puruṣa ucyate.

S. 5645: swawîryyam.... wai...., abhîto yudhyate çatrûn.... wai ....

J. hana sira umâçraye kaçaktin ri swaçarîra nira juga, sinyang nira pwa musuh nirâpranga, aprang pwa sira, tatan kapangpang wîryya nira de nikang musuh, samangkana krama nira, sira sinanggah mahâpuruṣa ngaran ira: "er is iemand, die slechts zijn toevlucht zoekt in zijn eigen kracht, die zijne vijanden ten strijde uitdaagt, hij strijdt zonder dat zijne vijanden zijne dapperheid kunnen weerstaan, wie zoo handelt, die wordt een groot man genoemd, " 
De O.J. vertaling van het Ulûkadûtâgamanaparwa ${ }^{1}$ eindigt op fol. a, 94 en loopt dus van fol. a, 91-a, 94, terwijl de Skr.-tekst 306 verzen bevat. (çl. 5407-5713).

\section{RATHâTIRATHASANGKHYâNAPARWA.}

J. fol. 94, r. 2: Nâmakṛtwa Kumârâya senânye çaktidhariṇe,

aham senâpatis te 'dyaḥ bhawiṣyâmi na sangçayaḥ.

S. 5720: Namaskṛtya .... çaktipânạy e,.... 'dy a....

J. aum mahârâja Duryyodhana, nghulun pinakasenâpatinta mangkay, haywa tâlunggah angönangěnmu, apan bhațâra Kumâra sẹ̣̆ěng nira n pinakasenâpati ning hyang kabeh, anuṣṭhâna ni nghulun, kâla nira ruměgęp lipung nira: "o koning Duryyodhana! ik ben nu uw legeraanvoerder, wees niet ongerust, want god Kumâra heeft, toen hij legeraanvoerder der goden geworden is, mij bevestigd, toen hij zijn speer aanvatte.»

J. fol. 96, r. 1: Rathânâm kwa ca wijñânam kwa ca Bhîșmâlawetanah,

S. 5829a: .... Bhîșmo 'lpacetanah.

J. kapana ng Bhîșma wruha ri kalingan ing maratha: "Hoe zou Bhîșma de wetenschap der wagenmenners kennen?»

Het slot van het Skr. vers is dus niet vertaald.

J. fol. a, 97, r. 3: Nâghayutasâma prâṇa $=$ S. $5854 a:$ nâgâyutabalo mânî.

J. sakaçaktining liman sâyuta pinakawîryya sarika: "hij is zoo sterk als 10.000 olifanten in zijne dapperheid.»

J. fol. a, 98, r. 2: Pañcâlan tu mahâbatum nâham hanyâm Çikaṇdịnạ ,

udyatemu piga prakșya pratiyuddhyantam âhawe.

S. 5936: Pâñâlyan.... mahâbâho.... Çikhạ̣ ḍinamin, udyateșumatho dṛṣțwâ....

J. ikang Çikaṇ̣̣i juga ya tan wĕnang umatî ya, yadyapin tihangakna juga panahnya tuwi lumagana nghulun, tan lepasana yan astrângka ri těngah ning rạ̣a: "Alleen Çikhaṇ ḍin mag (ik) niet dooden, zelfs al spant hij zijn boog, om mij te bestrijden, zal ik mijn pijl niet afschieten midden op het slagveld.»

In het hs. staat astrângka, doch ik heb vertaald, alsof er stond astrangku.

1 Zie over den inhoud van dit parwa Holtzmann, o. c. p. 115-116. 
J. fol. 98 , r. 1: Ahi strîpûrwwako râjan Çikạ̣ḍi yadi te çrutâ,

kanyâ bhûtwâ pumân jatoḥ na yotsye tena Bhagatah. S. 5940: Sa hi.... Çikhạ̣ḍ̂.... çrutạ̣,... jâto.... Bhârata.

J. iki Çikaṇ̣̣i ya ta strîpûrwwaka, karěngö marapwa kacaritanya, an mûlakanyâ, matěmahañ jalu wěkasan, tatan aprangâku lâwan ikâ: "deze Çikhaṇḍin is vroeger eene vrouw geweest, naar hetgeen verhaald wordt, zou hij oorspronkelijk eene maagd geweest zijn, maar ten slotte een man geworden zijn, ik zal niet strijden met hem.»

Hier eindigt het Rathâtira thasangkhyânaparwa ${ }^{1}$. Het loopt van fol. a, 94-98, terwijl het in den Sanskrttekst 227 verzen bevat (çl. 5714-5941).

\section{AmbopâKHYânA.}

J. fol. a, 100 , r. 1: Bhaktânâm hi parityagaḥ na dharmeșu yatisyate.

S. $5987 b: \ldots$ parityâgo.... praçasyate.

J. i patulak ning wwang jalujalu ring strî marâhyun rakwa, adharmmasâdhana ngaran ikâ: "dat een man eene vrouw verstoot, die verlangend tot hem komt, dat heet eene onrechtvaardige handelwijze.»

J. fol. a, 100 , r. 4: Twayâ tyakâ gamasyami yatra yatra wiçâmpate,

tatra me santu gatayah santa satya yawa wrawit.

S. $5997: \ldots$ tyaktâ gamiṣyâmi .... tatra ...., .... gatayạ santu santah satyam yathâ dhruwam.

J. kita harah mahârâja Çâlwa tuminggalakěn nghulun, katuhwan karika wih, lumakwa ta nghulun mangke, ikang deça parana ni nghulun, tan hilanga juge sagati ni nghulun, tan pakântang tan âmběka tan kasatyan: "Helaas, gij, koning Çâlwa, hebt mij verlaten, inderdaad zal ik nu gaan; in de streek, waarheen ik mij zal begeven, moge voor mij niet alle toevlucht te loor gaan, noch wat tot kalmte stemt, noch waarachtigheid.»

De O.Jav. vertaling is mij niet duidelijk. Vooral tanâmběka begrijp ik niet. Misschien is hierachter iets uitgevallen. Voor pakântang leze men pakânteng: wat strekt tot kalmte.

1 Zie Holtzmann, 1. c. p. 116. 
J. fol. 100 , r. 3: Ahosmit mitaram mûḍham yo me 'kârșît swayambaram,

mayâ 'yami swakosye doṣaḥ sa 'ham Bhîṣmarathât tadâ.

S. 6004: Atha wâ pitarami...,.... swakrto doṣo yâ....

J. atyanta kamûḍhan ing bapangku gumawayakĕn kaswayambarangku, apan mangke kapuharanya kapâpân magöng, uwih tělas kâlap ngarangku de sang âryya Bhîșma, inunggwakěn ring ratha: "buitengewoon groot was de dwaasheid van mijn vader, die mijne zelfkeuze van een echtgenoot bewerkte, want nu heeft dit een groote ramp veroorzaakt, mijn goede naam is mij ontnomen door den edelen Bhîșma, die mij op zijn wagen geplaatst heeft.»

J. fol. a, 101, r. 1: Dagma dak Çalparâjanam dig mâka padamuktamam.

S. 6007a: Dhing mâm dhik Çâlwarâjânam dhig dhâtâram athâpi wâ.

De laatste woorden van het in den O.J. tekst aangehaalde Skr.-vers zijn verbasterd uit: âpadam utta mâm (Calcutta-editie, vers $6007 b$ ult.)

J. samangke ta pwa kaçmala aku wit ning kahînapuṇyân, bapangku waneh mahâbhâra kamandabhâgyan sirân pakânak ni nghulun, sang hyang Brahmâ ta sira ganya, atyanta de nirâgaway wwang mangka lwirnya: "nu ben ik onrein tengevolge van mijne geringe verdiensten, ook mijn vader is zeer ongelukkig, dat hij mij tot kind heeft, en god Brahmâ buitengewoon, omdat hij iemand zooals ik ben geschapen heeft.»

J. fol. 101, r. 1: Macayawe tani karmmâṇi pûrwwadehe șu mụ̂̂hayâ,

kṛtâni nûnam pâpâni tepâm etan mahâphalam.

S. $6017 b$ en $6018 a$ : Mayaiwa yâni.... tu...., .... teșâm etat phalam dhruwam.

J. Atyanta hala ni kâryya göng ning durbuddhi ginawe ni nghulun, ngûnî pûrwwajanma, mûḍha tâku rânak ampu ring janma mangkana, matangnyan mangke phalâhala kapanggih de ning pinakanghulun satata: "groot is de slechtheid van mijne daden en de domheid van hetgeen ik in eene vroegere geboorte verricht heb, en ook in deze geboorte is uw kind dom, daarom ondervind ik nu steeds de slechte gevolgen daarvan.» 
J. fol. 101, r. 4: Alan prabhajiteneha bhadre çrpub hitan wacab,

ito badreçcaswa bhadra tatân ewa gamutyatab.

S. $6026 \ldots$ prawrajiteneha .... çṛu....,.... gacehaswa

bhadran te pitur.... niweçanam.

J. haywa kita lumakwa wiku paribrâjaka, us tânaku, nihan pajarkw iri kita, hitâwasâna ike wuwusku, at laku juga mulih ri bapanta: "gij moet niet rondtrekken als eene bedelnon, kom mijn kind, dit zeg ik tot $\mathrm{u}$, deze woorden van mij hebben een nuttig resultaat, ga toch en keer terug naar uwen vader!

J. fol. a, 102, r. 1: Patir wâ 'mi gati nâryyâh pitâ wâ carawarṇnani.

S. $6028 b: \ldots$ 'pi gatir.... warawarṇini.

J. pilih swâmi, pilih bapa kahanan ing kadi kita: «hetzij uw echtgenoot, hetzij uw vader is de plaats (van toevlucht) voor iemand zooals gij.»

J. fol. 102 , r. 4: Atah pitṛgrham bhadro mastu janako hyataham,

duham cetśyâmam te hawe maya warttasi putrake.

S. $6045 b$ en $6046 a$ : mâgâh.... bhadre mâtus te.... hỵ aham , duhkham chindyâm ahaṁ... wai mayi wartaswa...

J. bibîbu sang râjaputrî, ilu ndak ulihakěn kita ri bapanta, aku kakinta saka rîbunta, haywa ta kita sangçaya, aku âçraya pituhunta: "meisje, prinses! ga mede! Laat ik u terugbrengen naar uwen vader, want ik ben uw grootvader van moederszijde, wees niet ongerust, vertrouw op mij als uw toevlucht!»

J. fol. 103 , r. 2 : Bhawantam ewa satatam rameh kirttiyate wibho,

Sañjayo me priyasaka râjarṣir idi pârthiwah.

S. 6064 :.... Râmah kîrttayati prabho, Sṛnjayo me priyasakho.... iti pârthiwa.

J. sojar rahadyan sanghulun, bhagawân Hotrawâha, nora waneh pangucap nira bhagawân Paraçurâma, bheda sangke rahadyan sanghulun, anghing ya pinakâsih i nghulun bhagawân Hotrawâha, âryya Sañjaya haran ira waneh, râjaṛsi mûlaratu cakrawartti, mangkana ling nirâmucap rahadyan sanghulun sarisari: "zooals gij zegt, heer Hotrawâha, niet anders zijn de 
woorden van heer Paraçurâma, behalve gij, wordt slechts hij bemind door mij, heer Hotrawâha, de edele Sañjaya is een andere naam van hem, een koninklijke ziener, van oorsprong een wereldheerscher, zoo luiden zijne woorden tot u dagelijks.»

J. fol. 104, r. 1: Yadi twâm âpageyo weḥ na' nayed Bhajasanahna,

Salwasam çirasâ bhiruh hṛniyât Râmacoditaḥ.

S. 6092:... wai.... Gajasâhwayam, Çâlwas twâm.... bhîru gṛhṇîyâd....

J. ya tan hana sanmata nika sang Bhîșma ri waluyanta kita ring Gajâhwaya, tan wurunga sang Çâlwarâja tumangan kalih ta kita, yan apa, yan uddeça bhagawân Râma paraçu: "Wanneer Bhișma niet toestemt, dat gij terugkeert naar Gajâhwaja, zal het niet falen, dat koning Çâlwa u beiden huwt, vooral, wanneer heer Paraçurâma daartoe aanspoort.»

J. fol. 104, r. 1: Tato Râmaḥ prâdur âsît $=$ S. $6098 a$ init.

J. ḍatěng ta bhagawân Paraçurâma: "toen kwam heer Paraçurâma.»

J. fol. a, 105, r. 2: Râmeyam mama dehitri Kâçirâjasutâ prabho,

asyâh çṛ̣u yathâtatwam kâryya kâryyawinaṣanam.

S. 7004:... dauhitrî....,.... kâryyam kâryyawiçârada.

J. sâjñâ rahadyan sanghulun maharṣi! Iking rare strî putu ni nghulun sakeng anak strî, anak sang mahârâja Kâçipura, yatikâ katatwan ikâ, matangnyan mangkana, lâwan prayojana nike, yatika rĕngön rahadyan sanghulun: "met uw verlof, groote ziener! Dit meisje is mijne kleindochter, het kind mijner dochter, de dochter van den vorst van Kâçipura, dat is hare afkomst, de reden daarvan en het doel daarvan, moogt gij dat vernemen.»

J. fol. a, 106, r. 2: Mamâtya wyasanasyâsya Bhîșmo muli mahâbrata,

yeneyam waçam ânîtâ samutpyawya walat tadâ.

S. 7020: Mama tu.... mûlam் mahâwrataḥ, yenâham.... samutkṣipya balât....

J. paramârthanya sang Bhîșma juga padârtha ning pinakanghulun rasikâ, gumawe kadînâkna ra putu sang pạ̣dita, apan rasikâ walâtkâra, umalap ing pinakanghulun kari ng swayambara: 
"de reden daarvan is, dat Bhîșma de aanleiding was, dat uwe kleindochter vernederd is, want hij heeft immers geweld gepleegd, toen hij mij bij de zelfkeuze nam.»

J. fol. 107, r. 1: Na bhayân nasy ajukroçân na lobhan nârtha kâmyayâ.

kṣatriyadharmmam ijñâhyam iti me bratapahitam.

S. $7060: . .$. nâpy anukroçân nârthalobhân na...., ksât-

tram் dharmmam aham jahyâm.... wratam âhitam.

J. ikâ ta matangnyan nghulun matinggal swadharmma ning kṣatriya, i wěnang ni nghulun mehakna ng râjaputrî ri paraprabhu, tan saka ri takut, tan saka ring asih, tan kalobhan kâraṇanya, tan saka ring hyun wehana mâs, apa pwa, de ning pagěh ni brata ni nghulun si brâhmacârî: "dit nu is de reden, dat ik de plichten van een kṣatriya verzaak, omdat ik gerechtigd ben, de koningsdochter (ten huwelijk) te geven aan een vorst, niet uit vrees, niet uit genegenheid, niet begeerte is de reden daarvan, niet ten gevolge van den wensch, om goud te ontvangen. Wat dan? Wegens de vastheid van mijne gelofte als Brâhmacârin.»

J. fol. 107 , r. 3 : Kin twam wa yoddham iccasi $=$ S. $7064 b$ : (abruwam kâraṇam) kin tat yat twam yuddham mayecchasi.

J. apa ta hetu sang paṇḍita maharép mapranga lâwan pinakanghulun: "Wat is toch de reden, dat de wijze wil strijden met mij?»

J. fol. 108 , r. 3: Tatas tatra dwijâ râjan tâpasaç ca panokaça,

apasantwa rạ̣am diwyam dewas sârșigaṇas tatâ.

S. $7110: \ldots$ râjamis tâpasâç̧̧a wanaukasaḥ, a paçyanta.... dewâh ṣ sendragaṇâs tadâ.

J. irikâ ta sang watěk maharși sang tamolah ing patapan haneng alas, mwang watěk dewatâsiddhagaṇa: "toen (keken) alle groòte zieners, die zich bevonden in de kluizenarij in het woud en alle scharen van goden en siddha's.»

Het verbum ontbreekt in de O.Jav. vertaling, daar de tekst hier eene lacune vertoont.

Dit is het laatste vers uit den Sanskrtt-tekst, dat in de O.Jav. bewerking geciteerd wordt. Eenige regels verder staat: Iti Udyogaparwwa, i çâka, 1747. Hieruit blijkt dus, dat dit HS. 
geschreven is in Çâka $1747=1825$ A.D. De tekst eindigc abrupt met de woorden: Mangke yatah prang ni nghulun lâwanta weh kadi nghulun, tikâ tlas angasihasih gati ni nghulun ngûni, kunang apan hyunya meha kâ....

Ten slotte nog twee opmerkingen: de woorden van Holtzmann (Zur Geschichte und Kritik des Mahābhārata, I, 158): «Die Regeln des Sandhi werden in einzelnen Fällen durchaus nicht ängstlich beobachtet» zijn vooral op de Sanskṛtverzen in den O.-J. tekst toepasselijk. Alle episoden, die thans in den Sanskrttekst voorkomen, zooals de Indrawijaya en de Ambopâkhyâna, maakten blijkbaar reeds in de $11^{\mathrm{e}}$ eeuw een deel uit van den Sanskṛttekst. 